\title{
Leadership Practiece Among Nurses in Tertiary Care Hospital Lahore
}

\author{
Firdous Akbar Muhammad Afzal Muhammad Hussain Syed Amir Gilani \\ Lahore School of Nursing, The University of Lahore, Lahore, Pakistan
}

\begin{abstract}
Introduction: The planned role of leadership can be used to examine on how to engage leadership models and use leadership behavior to progress organizational performance. The intangible assets such as leadership styles, culture, skill and competence, and motivation are key sources of strength in firms that can combine people and processes and organizational performance.

Methodology: Leadership Practices - Self assessment and Leadership Practices - Observer: The data collection tool was used for this study is self-assessment scale. It was designed in 1987 to be utilized by a leader to selfevaluate them in how frequently they engage in leadership practices. The thirty descriptive statements are given and a Likert scale was used. The five practices are identified as challenge the process, inspire a shared vision, enable others to act, model the way, and encourage the heart same repeatedly question asked from nurses to assess the perception (Posner \& Kouzes, 1988).

Results: The study revealed that the managers moderately performed the leadership practices. A significantly positive relationship was found between the manager and subordinate's assessment of challenging the process and inspiring a shared vision $(\mathrm{p}=.345)$.

Discussion: the results of this study support the existence of a relationship between the self-assessment and the subordinate's assessment. This study also indicates that the managers in this study moderately exhibited the leadership practices as identified in Kouzes and Posner's (1987) research.
\end{abstract}

DOI: $10.7176 / \mathrm{JHMN} / 60-06$

Publication date:March $31^{\text {st }} 2019$

\section{INTRODUCTION \\ Background of study \\ Abstract}

A need was also observed for nursing leaders to reflect and self-evaluate their leadership considering perceptions from the team on their adopted actions and practices, as the leadership practices are powerful indicators of the performance of the work of the nursing team (Eneh, et al., 2012)

The planned role of leadership can be used to examine on how to engage leadership models and use leadership behavior to progress organizational performance. The intangible assets such as leadership styles, culture, skill and competence, and motivation are key sources of strength in firms that can combine people and processes and organizational performance (Khan, Bukhari, \& Channar, 2016).

Nurses face diverse challenges while providing the heath care facilities, so, self-confidence and strong believe on the self-capabilities help them to cope with these challenges. Thus, employee's self-esteem plays a crucial role in the efficient health care services. Moreover, self-esteem is associated with the encouragement of head nurses and it ultimately influences the patient care (McGrath, Taenzer, Karon, \& Blike, 2016).

Leadership takes practice. Leadership is not a role that is practiced once and then mastered. Nurse leaders who encounter complicated issues should not rush to resolve them thus, the combination of established leadership styles is highly recommended for nurse leaders in clinical settings since various leadership styles and theories are relevant to nursing practice. Nurse Managers and clinical leaders should acknowledge the advantages and disadvantages of each theory $(\mathrm{Xu}, 2017)$.

Collaborative practice with the nursing staff and effective management of individual is the patient care needs. Implementation of the APN role resulted in very positive perceptions of communication between the nursing staff and the APN/medical team; improved communication of the written plan of care; and learning opportunities for the nursing staff (Keenan, Mutterback, Velthuizen, Pantalone, \& Gossack-Keenan, 2018).

Challenge the Process does not mean challenge the values or standards, just because uncompromising integrity or flawless quality are too hard to live by. It does not mean attacking other people when we don't agree with their ideas or points of view. Nor does it mean seeking to dismantle what is working well, or attempting to eliminate something that is simply a personal inconvenience for you. Challenge the Process is about finding and implementing new and better ways of doing things in order to constantly improve to grow (Clinton, 2017).

Leaders passionately believe that they can make a difference. They envision the future creating an ideal and unique image of what the organization can become. Through their magnetism and quite persuasion, leaders enlist others in their dream. They breathe life into their visions and get people to see exciting possibilities for the future (J. Kouzes \& Posner, 2013). 
Leader foster collaboration and build spirited team. They activity involve others. Leaders understand that mutual respect is what sustains extraordinary efforts. They strive to create an atmosphere of trust and human dignity. They strengthen others, making each person feel capable and powerful (Goewey, 2012).

Leaders establish principle concerning the way people, peers, colleagues, and customers alike, should be treated and the way goal should be pursued. They create excellence standard and set an example for others to follow, because the prospect of complex change can over people and stifle action they set interim goals so that people can achieve small wins as they work towards large objectives (J. Kouzes \& Posner, 2013).

Accomplishing extraordinary thing in organization is hard work. To keep hope and determination alive, leaders recognize contributions that individual make. In every winning team, the members need to share in the rewards of their efforts, so the leaders celebrate accomplishment. They make feel like heroes (al-Baradie, 2014).

The impact of leadership practices on organization: The largest and diverse work forces in the health care system are the Nurses. Quality of work life is an essentiality of the nurses where she is able to satisfy her personal needs through rendering a quality care to the patient's and achieving the organizational goals. In nursing outlook, Brooks define the quality of work life as "the degree to which nursing leadership are able to satisfy important personal needs through their experiences in their work organization while achieving the organization's goals" (Gayathiri, Ramakrishnan, Babatunde, Banerjee, \& Islam, 2013).

\section{Research Problem}

In recent years, the issues of leadership practices have become important topics in all fields of work even in politics and especially in health care sectors. Nursing leaders play key role in shaping the nurses profession to be more responsive to changing health care system than and as well as become a role model for sub ordinaries. Effective leadership practices of healthcare professionals are countable for strengthening quality and integration of care. Leadership practices was found to be strongly correlated with quality care (Sfantou et al., 2017).

Leaders who do not measure patient satisfaction lack information on quality improvement, which may result in decreased organizational performance (Kleefstra, Zandbelt, de Haes, \& Kool, 2015). The general business problem was that some hospital leaders who fail to respond to poor patient satisfaction reports may experience lower organizational performance (Heppell, 2016). Hospitals with the lowest satisfaction scores generate $21 \%$ more health care costs (Lieber, 2014).

In study setting it is observed that the leaders are not well known with their role and job description and even not with authority. There for their practices are not much effective. That's why they are unable to guide there sub ordinates in formal manner. Other thing in observation is punctuality which not followed specially in public health care by leaders. On the other hand leaders are the role model for their sub ordinates if the leader did not practiced well obviously the sub ordinates adopt and performed accordingly. According to this situation it is keen desire to assess the leadership practices in the Jinnah hospital

\section{Research Purpose}

The purpose of this study is to assess the leadership practices and relationship between leaders self and subordinate point of view regarding leadership practices in tertiary care hospital Lahore Pakistan.

\section{Research question}

What are the leadership practices and relationship between leaders self and subordinate point of view regarding leadership practices in tertiary care hospital Lahore Pakistan?

\section{Significance of the study}

Patients: The finding of the study may help the team leader to improve leadership practices, therefore nurses' performance will improve and ultimately quality of care and patient satisfaction will improve.

Health Care Provider: The current study will be beneficial for nurses because after completion of this study the nurses will know and understand the best practices of leadership, in future being leader then they will perform well in ward and in any situation they faced and will lead their team in a cooperative manner with clear instructions.

Organization: The Finding of the study might be helpful for the organization to develop the strategies to improve leadership practices through training session, workshop, and seminar in result skills of nurses will be improve and ultimately this will improve the working environment and quality of care. It will be suitable for the hospital management to take necessary steps to find the weak factors which produce and enhance mal-practices among leaders and take suitable remedial steps to control and prevent adverse events. The result cans also assist the organization to better understand how nurses work life and productivity affected by the leader ship.

Future Research: The current study will provide baseline data and the way for further research and will identify the remaining gaps.

Variables of Study

Independent variable: Head nurse, Charge nurses, Demographic factors

Dependent variable: Leadership practices

Conceptual Definition

Leadership: Leadership is the art of mobilizing others to want to struggle for the shared aspirations (Rost, 1993). Leadership practices: Five leadership practices are: challenging the process, inspiring a shared vision, enabling 
others to act, modeling the way, and encouraging the heart to become an extra ordinary leader

Charge nurses: Nursing encompasses autonomous and collaborative care of individuals of all ages, families, groups and communities, sick or well and in all settings. Nursing includes the promotion of health, prevention of illness, and the care of ill, disabled and dying people (Shaw, 2007).

Operational Definition:

Leadership: The art of leader working in health care sector to mobilize sub ordinates to achieve the goal.

Leadership practices: The practice that a leader used to manage the sub ordinates working in Jinnah hospital. Charge nurses: A person working in health care sector and responsible for to take care the sick and injured person.

\section{MATERIAL AND METHODS}

Study Design

A quantitative cross-sectional Analytical study design was used.

Study site

The study was conducted in Jinnah Hospital, Lahore.

\section{Study Setting}

The data was collected from charge nurses working in medicine ward, surgical ward, Peads

Ward, Gynae ward, cardiac ward and from departmental head nurses except Operation Theater.

Study Population

Study papulation was 160 staff nursesand 140 head nurses.

Inclusion Criteria

The inclusion criteria for this study were:

- Female head nurses

- Female registered nurse

- Willing to participate

- More than one year experience

- 23-58 years of age

Exclusion Criteria

The exclusion criteria will be:

- Nursing Student

- Not willing to participate

- $\quad$ Age below 23 years and above 58 years.

Sampling Technique

A convenient sampling technique was used for this study.

Sample Size

Sample size was calculated by using "Slovins formula".

$$
\mathrm{n}=\mathrm{N} / 1+(\mathrm{N})(\mathrm{E})^{2}
$$

$\mathrm{N}=$ Population 304, $\quad \mathrm{n}=$ Sample size $=? \quad \mathrm{E}=0.05 \%$ Margin of error $\quad$ Confidence interval $95 \%$

$$
\mathrm{n}=\mathrm{N} / 1+(\mathrm{N})(\mathrm{E})^{2}
$$

$\mathrm{n}=300 / 1+(304)(0.05)^{2}$

$\mathrm{n}=300 / 1+(304)(0.0025)$

$\mathrm{n}=300 / 1+0.76$

$\mathrm{n}=300 / 1.76$

$\mathrm{n}=170$

The sample size for this study was 170 .

Ethical Consideration/Institutional Review Board

Written permission will be taken from the Ethical committee of LSN department in University of Lahore. Permission will be taken from the Deputy Nursing Superintendent of Social Security Hospital Lahore to conduct research study. Subjects have fully freedom to participate in this study. All the participants will be informed about the purpose of the study. The subject will be informed that there are no disadvantages or risk on the procedure of the study.

\section{Data Collection Instrument}

Three instruments were used to collect data for this research study

- Demographic variables

- Leadership Practices - Self assessment questionnaire

- Leadership Practices - Observer questionnaire

Data Analysis Method

A statistical package for social sciences SPSS version 21 will use to analyze the data. Descriptive analyses will 
use to describe the sample. Frequency distributions will calculate for gender, age, educational level, experience. Mean values will be calculated for the various rankings given for leadership practices. Kolmogorov-Smirnov and Shapiro-Wilk test was used to check the normality of data. Pearson correlation test was used for relationships between Leadership Practices - Self assessment and Leadership Practices - Observer.

\section{RESULTS}

This study was conducted at Jinnah hospital to determine the leadership practices. The result of this study distributed into two sections, first section is statistics of demographic factors, independent and dependent tools named Leadership Practices - Self assessment and leadership practices - observer perception. Second section is relationship between demographic factors, Leadership Practices - Self Assessment and Leadership Practices Observer Perception.

\section{Section 1:}

Demographic factors frequencies for leadership practices self-assessment

Table 1 shows that only the female $85(100 \%)$ were participate in this study with age group 23-31 years old were $27(31.8 \%)$ and 32-40 years old were $45(52.9 \%), 41-49$ years old were $13(15.3 \%)$. however near to $42(49.4 \%)$ participants were general nursing diploma holder, and $40(47.1 \%)$ were hold a degree of bachelor of sciences in nursing post Registered nursing and only 3 (3.5\%) participants with degree of bachelor of sciences in nursing generic. Frequency percentage of experience of participants and the results were 1-9 years 41 (48.2\%) in majority, $10-18$ years $38(44.7 \%), 19-27$ years experienced participants were only $6(7.1 \%)$.

Table 1

\begin{tabular}{|c|c|c|c|c|c|}
\hline \multicolumn{4}{|c|}{ Demographic Variable } & \multirow{2}{*}{$\begin{array}{l}\text { Frequency } \\
85\end{array}$} & \multirow{2}{*}{$\frac{\text { Valid Percen }}{100 \%}$} \\
\hline Gender: & Female & & & & \\
\hline \multirow{4}{*}{ Age: } & 23-31 years & & & 27 & $31.8 \%$ \\
\hline & $32-40$ years & & & 45 & $52.9 \%$ \\
\hline & 41-49 years & & & 13 & $15.3 \%$ \\
\hline & Total & & & 85 & $100 \%$ \\
\hline \multirow{4}{*}{ Experience: } & 1 & 9 & years & 41 & $48.2 \%$ \\
\hline & 10 & 18 & years & 38 & $44.7 \%$ \\
\hline & 19 - 27 years & & & 6 & $7.1 \%$ \\
\hline & Total & & & 85 & $100 \%$ \\
\hline \multirow{3}{*}{ Qualifications: } & General Nursing & & & 42 & $49.4 \%$ \\
\hline & Bachelor of Scien & $\mathrm{g}($ Post RN) & & 40 & $47.1 \%$ \\
\hline & Bachelor of Scien & $\mathrm{g}$ (Generic) & & 3 & $3.5 \%$ \\
\hline
\end{tabular}

Figure 1 shows that only the female $85(100 \%)$ were participate in this study.

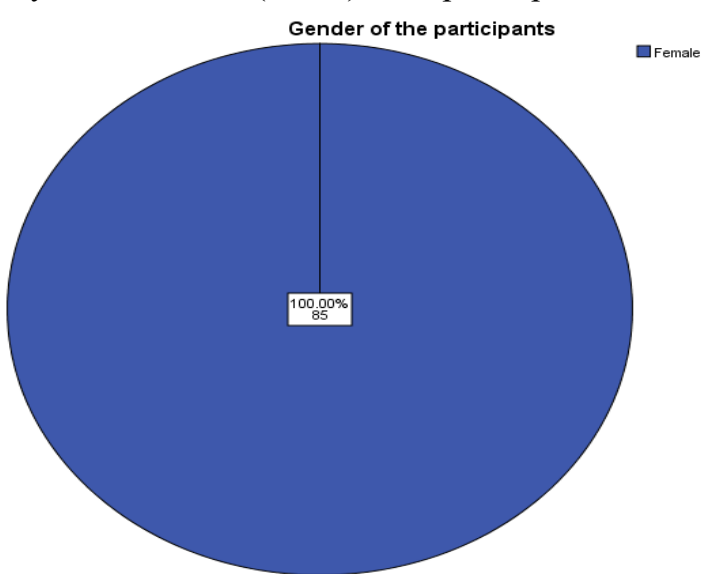

Figure 1

Figure 2 this study revealed that the participants participate with age group 23-31 years old were 27 (31.8\%) and $32-40$ years old were $45(52.9 \%), 41-49$ years old were $13(15.3 \%)$. 


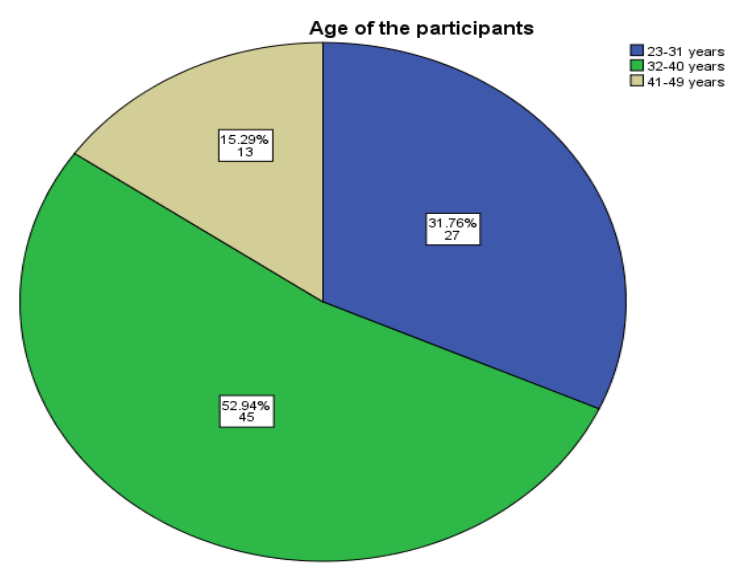

Figure 2

Figure 3 shows Frequency percentage of experience of participants and the results were 1-9 years $41(48.2 \%)$ in majority, 10-18 years $38(44.7 \%), 19-27$ years experienced participants were only $6(7.1 \%)$.

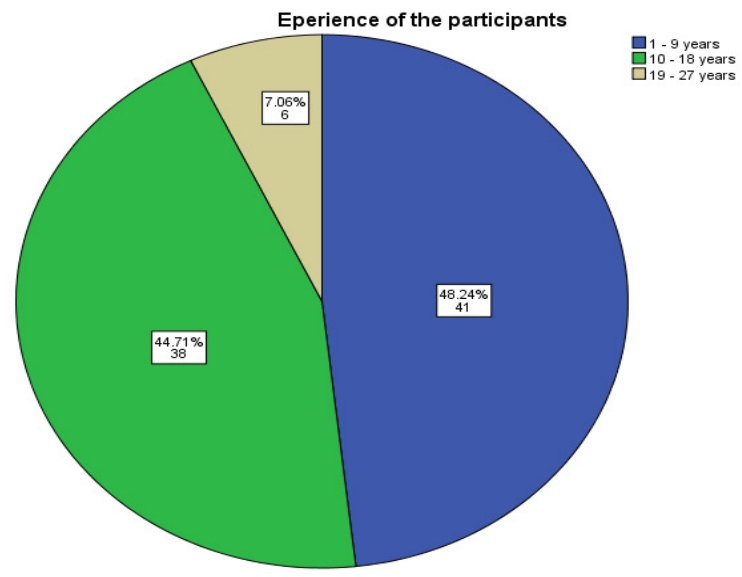

Figure 3

Figure 4 near to $42(49.4 \%)$ participants were general nursing diploma holder, and 40 (47.1\%) were hold a degree of bachelor of sciences in nursing post Registered nursing and only $3(3.5 \%)$ participants with degree of bachelor of sciences in nursing generic.

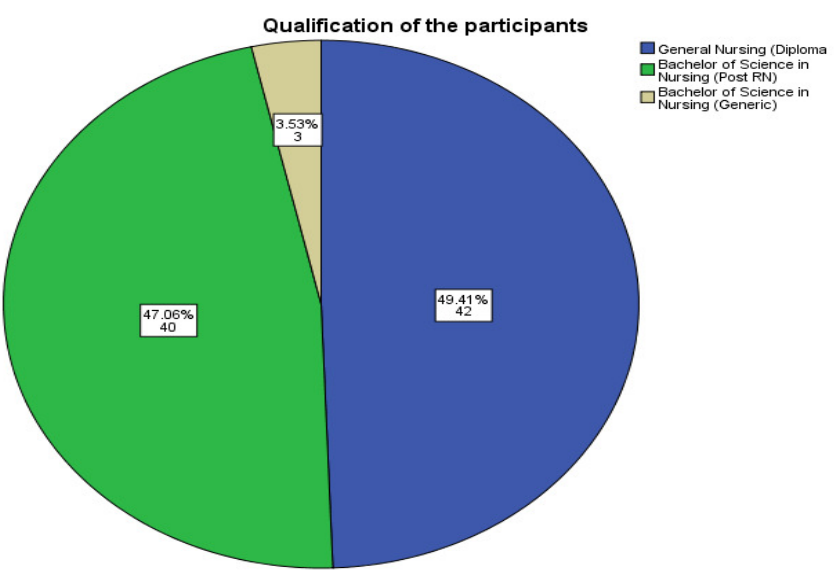

Figure 4

Demographic factors statistics for leadership practices self-assessment

Table 2 show that mean, median, mode, standard deviation and variance of gender, age, experience, and qualification of the participants and the mean $(1.00,1.84,1.59,1.54)$, median $(1.00,2.00,2.00$, and 2.00), mode $(1,2,1,1)$, standard deviation $(.000, .670, .623, .568)$ and variance $(.000, .449, .388, .323)$ respectively 
Table 2

\begin{tabular}{lcccc}
\hline Statistics & $\begin{array}{c}\text { Gender of the } \\
\text { participants }\end{array}$ & $\begin{array}{c}\text { Age of the } \\
\text { participants }\end{array}$ & $\begin{array}{c}\text { Experience of the } \\
\text { participants }\end{array}$ & $\begin{array}{c}\text { Qualification of the } \\
\text { participants }\end{array}$ \\
\hline $\mathrm{N}$ & 85 & 85 & 85 & 85 \\
Mean & 1.00 & 1.84 & 1.59 & 1.54 \\
Median & 1.00 & 2.00 & 2.00 & 2.00 \\
Mode & 1 & 2 & 1 & 1 \\
Std. Deviation & .000 & .670 & .623 & .568 \\
Variance & .000 & .449 & .388 & .323 \\
\hline
\end{tabular}

\section{Leadership practices - Self assessment frequency}

Table 3 shows the participants response on the items of Leadership practices - Self assessment and frequency of participants from rarely orVery Seldom $=1$, Once in a While $=2$ Sometimes $=3$ Fairly Often $=4$ Very frequently or Almost Always = 5 and the result revealed that22 (25.9\%) Once ina While, 14 (16.5\%) Sometimes, $24(28.2 \%)$ Fairly Often, and majority25 (29.4\%) were agree with Almost Always regarding the "I seek out challenging opportunities that test his or her skills and abilities". 7 (8.2\%) agree with Rarely, 16(8.8\%) agree with Once in a While, $8(9.4 \%)$ participants response as Sometimes and majority $27(31.8 \%)$ were response as Fairly Often and $26(30.6 \%)$ in response of item two which was "I describe the kind of future he or she would like for us to create together". In the response of item three which was "I involve others in planning the actions that will be taking". $13(15.3 \%)$ agree with rarely, majority $30(35.3 \%)$ Once ina While, $15(17.6 \%)$ select Sometimes6 (7.1\%) agreed with Fairly Often and $21(24.7 \%)$ were select Almost Always.

Item four was 'I am clear about his or her own philosophy of leadership' and participants respond as 16 $(18.8 \%)$ rarely, majority $27(31.8 \%)$ Once ina While, only $15(17.4 \%)$ agree with Sometimes, 15 (17.4\%) Fairly Often and $12(14.1 \%)$ agree with Almost Always. In the reaction of question five which was "I take the time to celebrate accomplishments when project milestones are reached" $29(34.1 \%)$ rarely, majority $39(45.9 \%)$ Once in a While, $12(14.1 \%)$ Sometimes, $4(4.7 \%)$ agree with Fairly Often, 1(1.2\%) agreed with Almost Always. In the reaction of item six which was "My I stay up-to-date on the most recent developments affecting our organization" only 3 (3.5\%) agree with Once ina While, 19 (22.4\%) Sometimes and 29 (34.8\%) agreed with Fairly Often and majority $34(40 \%)$ select Almost Always. Item seven was "I appeals to others to share his or her dream of the future as their own" and the participant respond as only $4(4.7 \%)$ go with rarely, majority $23(27.1 \%)$ agree with Once in a While, 14 (16.5\%) Sometimes, 20 (23.5\%) Fairly Often, 24 (28.2\%) agree with Almost Always. Item eight was "I treat others with dignity and respect." and response was only $3(3.5 \%), 5 .(5.9 \%)$ participants respectively agreed with rarely and Once ina While, 33 (38.8\%) Sometimes, majority 47 (47.1\%) Fairly Often, 4 (4.7\%) go with almost always. In the reaction of item nine which was "I make certain that the projects he or she leads are broken down into manageable step" only $3(3.5 \%)$ agree with rarely, $23(27.1 \%)$ Once in a While, 13 (15.3\%) Sometimes, 18 (21.2\%) Fairly often, 28 (32.9\%) participants were agreed with almost always. In the reaction of item ten which was "I make sure that people are recognized for their contributions to the success of our projects" 22 (25.9\%) Once in a While, 14 (16.5\%) Sometimes, 24 (28.2\%) Fairly often, 25 (29.4\%) participants were agreed with almost always.

$16(18.8 \%)$ participants were agreed with rarely, 8 (9.4\%) Once in a While, $27(29.8 \%)$ Sometimes, 26 $(30.6 \%)$ Fairly Often, and majorityl (1.2\%) were agree with Almost Always regarding the "I Challenges the way we do things at work".0agree with Rarely and Once in a While respectively, $16(18.8 \%)$ participants response as Sometimes and majority 34 (40\%) were response as Fairly Often and 35(41.2\%) in response of item twelve which was "I clearly communicate a positive and hopeful outlook for the future of our organization". In the response of item thirteen which was "I give people a lot of discretion to make their own decisions". $16(18.8 \%)$ agree with rarely, majority 27 (31.8\%) Once in a While, $15(17.6 \%)$ select Sometimes15 (17.6\%) agreed with Fairly Often and $12(14.1 \%)$ were select Almost Always. Item fourteen was "I spend time and energy making certain that people adhere to the values that have been agreed on and participants respond as $29(34.1 \%)$ rarely, majority 39 (45.9\%) Once ina While, only 12 (14.1\%) agree with Sometimes, 4 (4.7\%) Fairly Often and 1 (1.2\%) agree with Almost Always. In the reaction of question fifteen which was "I praises people for a job well done" 0rarely, 4 (4.7\%) Once ina While, 8 (9.4\%) Sometimes, 33 (38.8\%) agree with Fairly Often, majority 40 (47.1\%) agreed with Almost Always. In the reaction of item sixteen which was "I look for innovative ways we can improve what we do in this organization" 0 rarely and Once in a While, 13 (15.3\%) Sometimes and 35 (41.2\%) agreed with Fairly Often and majority 37 (43.5\%) select Almost Always. Item seventeen was "I show others how their long-term future interests can be realized by enlisting in a common vision" and the participant respond as only $2(2.4 \%)$ go with rarely, majority $12(14.1 \%)$ agree with Once in a While, 14 (16.5\%) Sometimes, 22 (25.9\%) Fairly Often, 35 (41.2\%) agree with Almost Always. Item eighteen was "I develop cooperative relationships with the people he or she works with." and response was only $3(3.5 \%)$ participants respectively agreed with rarely, majority $3(3.5 \%)$ agree with Once in a While, 3 (3.5\%) Sometimes, 29 (34.1\%) Fairly Often, 47 (55.3\%) agree with Almost Always. In the reaction of item nineteen which was "I let others know his or her beliefs on how to best run the organization he or 
she leads" only 3 (3.5\%) agree with rarely, 5 (5.9\%) Once ina While, 33 (38.8\%) Sometimes, 40 (47.1\%) Fairly often, $4(4.7 \%)$ participants were agreed with almost always. In the reaction of item twenty which was "I give the members of the team lots of appreciation and support for their contributions" 0 agree with rarely, $18(21.2 \%)$ Once in a While, $18(21.2 \%)$ Sometimes, $23(27.1 \%)$ Fairly often, $26(30.6 \%)$ participants were agreed with almost always. $0 \%$ participants were agreed with rarely, 29 (34.1\%) Once in a While, $21(24.7 \%)$ Sometimes, $17(20 \%)$ Fairly Often, and majority18 (21.2\%) were agree with Almost Always regarding the "I ask "What can we learn?" when things do not go as expected".2 (2.4\%)agree with Rarely, 12(14.1\%) agree with Once in a While,14 (16.5\%) participants response as Sometimes and $22(25.9 \%)$ were response as Fairly Often and 35(41.2\%) in response of item twenty two which was "I look ahead and forecasts what he or she expects the future to be like.". In the response of item twenty three which was "I create an atmosphere of mutual trust in the projects he or she leads". 0 agree with rarely and Once ina While, $3(3.5 \%)$ select Sometimes31 (36.5\%) agreed with Fairly Often and 51 $(60 \%)$ were select Almost Always. Item twenty four was "I am consistent in practicing the values he or she espouses" and participants respond as $11(12.9 \%)$ rarely, majority $17(20 \%)$ Once ina While, only $10(11.8 \%)$ agree with Sometimes, 25 (29.4\%) Fairly Often and 25 (29.4\%) agree with Almost Always. In the reaction of question twenty five which was "I find ways to celebrate accomplishments." Orarely, 22 (25.9\%) Once ina While, 14 (16.5\%) Sometimes, 24 (26.2\%) agree with Fairly Often, majority 25 (28.4\%) agreed with Almost Always.

In the reaction of item twenty six which was "I experiments and takes risks with new approaches to his or her work even when there is a chance of failure." 7 (8.2\%) rarely, $16(18.8 \%)$ agree with Once in a While, $8(9.4 \%)$ Sometimes and 27 (31.8\%) agreed with Fairly Often and majority 26 (30.6\%) select Almost Always. Item twenty seven was "I am contagiously excited and enthusiastic about future possibilities" and the participant respond as only $2(2.4 \%)$ go with rarely, majority $8(9.4 \%)$ agree with Once in a While, $13(15.3 \%)$ Sometimes, $32(37.6 \%)$ Fairly Often, $30(35.3 \%)$ agree with Almost Always. Item twenty eight was "I get others to feel a sense of ownership for the projects they work on" and response was $0 \%$ participants agreed with rarely, $6(7.1 \%)$ agree with Once in a While, 16 (18.8\%) Sometimes, 25 (29.4\%) Fairly Often, 38 (44.7\%) agree with Almost Always. In the reaction of item twenty nine which was "I makes sure the work group sets clear goals, makes plans, and establishes milestones for the projects he or she leads" only $2(2.4 \%)$ agree with rarely, $12(14.1 \%)$ Once in a While, 14 (16.5\%) Sometimes, 22 (25.9\%) Fairly often, 35 (41.2\%) participants were agreed with almost always. In the reaction of item thirty which was "I make it a point to tell the rest of the organization about the good work done by his or her group" 0 agree with rarely and Once in a While, $3(3.5 \%)$ Sometimes, 31 (36.5\%) Fairly often, $51(60 \%)$ participants were agreed with almost always.

Table 3

\begin{tabular}{|c|c|c|c|c|c|c|}
\hline SN & Self assessment questions & $\begin{array}{c}1 \\
\mathbf{f} \%\end{array}$ & $\begin{array}{c}2 \\
\mathbf{f} \%\end{array}$ & $\begin{array}{l}3 \\
\mathbf{f} \%\end{array}$ & $\begin{array}{c}4 \\
\text { f } \%\end{array}$ & $\begin{array}{l}5 \\
\mathbf{f} \%\end{array}$ \\
\hline \multirow[t]{2}{*}{1} & \multirow{2}{*}{$\begin{array}{l}\text { I seek out challenging opportunities that test his or } \\
\text { her skills and abilities. }\end{array}$} & 0 & 22 & 14 & 24 & 25 \\
\hline & & & $25.9 \%$ & $16.5 \%$ & $28.2 \%$ & $29.4 \%$ \\
\hline \multirow[t]{2}{*}{2} & \multirow{2}{*}{$\begin{array}{l}\text { I describe the kind of future he or she would like for } \\
\text { us to create together. }\end{array}$} & 7 & 16 & 8 & 27 & 26 \\
\hline & & $8.2 \%$ & $18.8 \%$ & $9.4 \%$ & $31.8 \%$ & $30.6 \%$ \\
\hline \multirow[t]{2}{*}{3} & \multirow{2}{*}{$\begin{array}{l}\text { I involve others in planning the actions that will be } \\
\text { taking. }\end{array}$} & 13 & 30 & 15 & 6 & 21 \\
\hline & & $15.3 \%$ & $35.3 \%$ & $17.6 \%$ & $7.1 \%$ & $24.7 \%$ \\
\hline \multirow[t]{2}{*}{4} & \multirow{2}{*}{$\begin{array}{l}\text { I am clear about his or her own philosophy of } \\
\text { leadership? }\end{array}$} & 16 & 27 & 15 & 15 & 12 \\
\hline & & $18.8 \%$ & $31.8 \%$ & $17.4 \%$ & $17.6 \%$ & $14.1 \%$ \\
\hline \multirow[t]{2}{*}{5} & \multirow{2}{*}{$\begin{array}{l}\text { I take the time to celebrate accomplishments when } \\
\text { project milestones are reached. }\end{array}$} & 29 & 39 & 12 & 4 & 1 \\
\hline & & $34.1 \%$ & $45.9 \%$ & $14.1 \%$ & $4.7 \%$ & $1.2 \%$ \\
\hline \multirow[t]{2}{*}{6} & \multirow{2}{*}{$\begin{array}{l}\text { I stay up-to-date on the most recent developments } \\
\text { affecting our organization. }\end{array}$} & & 3 & 19 & 29 & 34 \\
\hline & & 0 & $3.5 \%$ & $22.4 \%$ & $34.8 \%$ & $40.0 \%$ \\
\hline \multirow[t]{2}{*}{7} & \multirow{2}{*}{$\begin{array}{l}\text { I appeals to others to share his or her dream of the } \\
\text { future as their own. }\end{array}$} & 4 & 23 & 14 & 20 & 24 \\
\hline & & $4.7 \%$ & $27.1 \%$ & $16.5 \%$ & $23.5 \%$ & $28.2 \%$ \\
\hline \multirow[t]{2}{*}{8} & \multirow[t]{2}{*}{ I treat others with dignity and respect. } & 3 & 5 & 33 & 40 & 4 \\
\hline & & $3.5 \%$ & $5.9 \%$ & $38.8 \%$ & $47.1 \%$ & $4.7 \%$ \\
\hline \multirow[t]{2}{*}{9} & \multirow{2}{*}{$\begin{array}{l}\text { I make certain that the projects he or she leads are } \\
\text { broken down into manageable step. }\end{array}$} & 3 & 23 & 13 & 18 & 28 \\
\hline & & 3.5 & $27.1 \%$ & $15.3 \%$ & $21.2 \%$ & $32.9 \%$ \\
\hline \multirow[t]{2}{*}{10} & \multirow{2}{*}{$\begin{array}{l}\text { I make sure that people are recognized for their } \\
\text { contributions to the success of our projects. }\end{array}$} & 0 & 22 & 14 & 24 & 25 \\
\hline & & & $25.9 \%$ & $16.5 \%$ & $28.2 \%$ & $29.4 \%$ \\
\hline \multirow[t]{2}{*}{11} & \multirow[t]{2}{*}{ I Challenges the way we do things at work. } & 16 & 08 & 27 & 26 & 1 \\
\hline & & $18.8 \%$ & $9.4 \%$ & $29.8 \%$ & $30.6 \%$ & $1.2 \%$ \\
\hline \multirow[t]{2}{*}{12} & \multirow{2}{*}{$\begin{array}{l}\text { I clearly communicate a positive and hopeful outlook } \\
\text { for the future of our organization. }\end{array}$} & 0 & 0 & 16 & 34 & 35 \\
\hline & & & & $18.8 \%$ & $40.0 \%$ & $41.2 \%$ \\
\hline \multirow[t]{2}{*}{13} & \multirow{2}{*}{$\begin{array}{l}\text { I give people a lot of discretion to make their own } \\
\text { decisions. }\end{array}$} & 16 & 27 & 15 & 15 & 12 \\
\hline & & $18.8 \%$ & $31.8 \%$ & $17.6 \%$ & $17.6 \%$ & $14.1 \%$ \\
\hline
\end{tabular}




\begin{tabular}{|c|c|c|c|c|c|c|}
\hline SN & Self assessment questions & $\begin{array}{l}1 \\
\text { f } \%\end{array}$ & $\begin{array}{c}2 \\
\text { f } \%\end{array}$ & $\begin{array}{c}3 \\
\mathbf{f} \%\end{array}$ & $\begin{array}{c}4 \\
\text { f } \%\end{array}$ & $\begin{array}{c}5 \\
\text { f } \%\end{array}$ \\
\hline \multirow[t]{2}{*}{14} & I spend time and energy making certain that people & 29 & 39 & 12 & 4 & 1 \\
\hline & adhere to the values that have been agreed on. & $34.1 \%$ & $45.9 \%$ & $14.1 \%$ & $4.7 \%$ & $1.2 \%$ \\
\hline \multirow[t]{2}{*}{15} & I praises people for a job well done & 0 & 4 & 8 & 33 & 40 \\
\hline & & & $4.7 \%$ & $9.4 \%$ & $38.8 \%$ & $47.1 \%$ \\
\hline \multirow[t]{2}{*}{16} & I look for innovative ways we can improve what we & 0 & 0 & 13 & 35 & 37 \\
\hline & do in this organization. & & & $15.3 \%$ & $41.2 \%$ & $43.5 \%$ \\
\hline \multirow[t]{2}{*}{17} & I show others how their long-term future interests can & 2 & 12 & 14 & 22 & 35 \\
\hline & be realized by enlisting in a common vision. & $2.4 \%$ & $14.1 \%$ & $16.5 \%$ & $25.9 \%$ & $41.2 \%$ \\
\hline \multirow[t]{2}{*}{18} & I develop cooperative relationships with the people & 3 & 3 & 3 & 29 & 47 \\
\hline & he or she works with. & $3.5 \%$ & $3.5 \%$ & $3.5 \%$ & $34.1 \%$ & $55.3 \%$ \\
\hline \multirow[t]{2}{*}{19} & I let others know his or her beliefs on how to best run & 3 & 5 & 33 & 40 & 4 \\
\hline & the organization he or she leads. & $3.5 \%$ & $5.9 \%$ & $38.8 \%$ & $47.1 \%$ & $4.7 \%$ \\
\hline \multirow[t]{2}{*}{20} & I give the members of the team lots of appreciation & 0 & 18 & 18 & 23 & 26 \\
\hline & and support for their contributions. & & $21.2 \%$ & $21.2 \%$ & $27.1 \%$ & $30.6 \%$ \\
\hline \multirow[t]{2}{*}{21} & I ask "What can we learn?" when things do not go as & 0 & 29 & 21 & 17 & 18 \\
\hline & expected. & & $34.1 \%$ & $24.7 \%$ & $20.0 \%$ & $21.2 \%$ \\
\hline \multirow[t]{2}{*}{22} & I look ahead and forecasts what he or she expects the & 2 & 12 & 14 & 22 & 35 \\
\hline & future to be like. & $2.4 \%$ & $14.1 \%$ & $16.5 \%$ & $25.9 \%$ & $41.2 \%$ \\
\hline \multirow[t]{2}{*}{23} & I create an atmosphere of mutual trust in the projects & 0 & 0 & 3 & 31 & 51 \\
\hline & he or she leads. & & & $3.5 \%$ & $36.5 \%$ & $60 \%$ \\
\hline \multirow[t]{2}{*}{24} & I am consistent in practicing the values he or she & 11 & 17 & 10 & 25 & 25 \\
\hline & espouses. & $12.9 \%$ & $20.0 \%$ & $11.8 \%$ & $29.4 \%$ & $25.9 \%$ \\
\hline \multirow[t]{2}{*}{25} & I find ways to celebrate accomplishments. & 0 & 22 & 14 & 24 & 25 \\
\hline & & & $25.9 \%$ & $16.5 \%$ & $26.2 \%$ & $28.4 \%$ \\
\hline \multirow[t]{2}{*}{26} & I experiments and takes risks with new approaches to & 7 & 16 & 8 & 27 & 26 \\
\hline & his or her work even when there is a chance of failure. & $8.2 \%$ & $18.8 \%$ & $9.4 \%$ & $31.8 \%$ & $30.6 \%$ \\
\hline \multirow[t]{2}{*}{27} & I am contagiously excited and enthusiastic about & 2 & 8 & 13 & 32 & 30 \\
\hline & future possibilities & $2.4 \%$ & $9.4 \%$ & $15.3 \%$ & $37.6 \%$ & $35.3 \%$ \\
\hline \multirow[t]{2}{*}{28} & I get others to feel a sense of ownership for the & 0 & 6 & 16 & 25 & 38 \\
\hline & projects they work on. & & $7.1 \%$ & $18.8 \%$ & $29.4 \%$ & $44.7 \%$ \\
\hline \multirow[t]{2}{*}{29} & I makes sure the work group sets clear goals, makes & 2 & 12 & 14 & 22 & 35 \\
\hline & $\begin{array}{l}\text { plans, and establishes milestones for the } \\
\text { projects he or she leads }\end{array}$ & $2.4 \%$ & $14.1 \%$ & $16.5 \%$ & $25.9 \%$ & $41.2 \%$ \\
\hline \multirow[t]{2}{*}{30} & I make it a point to tell the rest of the organization & 0 & 0 & 3 & 31 & 51 \\
\hline & about the good work done by his or her group. & & & $3.5 \%$ & $36.5 \%$ & $60.0 \%$ \\
\hline
\end{tabular}

Note: Rarely or Very Seldom $=1$, Once in a While $=2$ Sometimes $=3$ Fairly Often $=4$ Very Frequently or Almost Always $=5$.

\section{Leadership practices-Self assessment statistics}

Table 4 shows the mean, median, mode, standard deviation, and variance of leadership practices- self assessment. High value of mean is 4.56 for item thirty that was "I create an atmosphere of mutual trust in the projects he or she leads" and lowest value of mean 1.93 for item five that was "I spend time and energy making certain that people adhere to the values that have been agreed on".

Table 4

\begin{tabular}{lllllll} 
SN & Self-assessment questions & Mean & Median & Mode & Deviation & Variance \\
\hline $\mathbf{1}$ & $\begin{array}{l}\text { I seek out challenging opportunities that test his } \\
\text { or her skills and abilities. }\end{array}$ & 3.61 & 4.00 & 5 & 1.166 & 1.359 \\
$\mathbf{2}$ & $\begin{array}{l}\text { I describe the kind of future he or she would like } \\
\text { for us to create together. }\end{array}$ & 3.62 & 4.00 & 4 & 1.371 & 1.880 \\
$\mathbf{3}$ & $\begin{array}{l}\text { I involve others in planning the actions that will } \\
\text { be taking. }\end{array}$ & 2.91 & 2.00 & 2 & 1.428 & 2.039 \\
$\mathbf{4} \quad \begin{array}{l}\text { I am clear about his or her own philosophy of } \\
\text { leadership? }\end{array}$ & 2.76 & 2.00 & 2 & 1.333 & 1.777 \\
$\mathbf{5} \quad \begin{array}{l}\text { I take the time to celebrate accomplishments } \\
\text { when project milestones are reached. }\end{array}$ & 1.93 & 2.00 & 2 & .884 & .781 \\
$\mathbf{6} \quad \begin{array}{l}\text { I stay up-to-date on the most recent } \\
\text { developments affecting our organization. }\end{array}$ & 4.11 & 4.00 & 5 & .873 & .762 \\
\hline
\end{tabular}


Std.

\begin{tabular}{|c|c|c|c|c|c|c|}
\hline SN & Self-assessment questions & Mean & Median & Mode & Deviation & Variance \\
\hline 7 & $\begin{array}{l}\text { I appeals to others to share his or her dream of } \\
\text { the future as their own. }\end{array}$ & 3.44 & 4.00 & 5 & 1.286 & 1.654 \\
\hline 8 & I treat others with dignity and respect. & 3.44 & 4.00 & 5 & .823 & .677 \\
\hline 9 & $\begin{array}{l}\text { I make certain that the projects he or she leads } \\
\text { are broken down into manageable step. }\end{array}$ & 3.53 & 4.00 & 5 & 1.296 & 1.681 \\
\hline 10 & $\begin{array}{l}\text { I make sure that people are recognized for their } \\
\text { contributions to the success of our projects. }\end{array}$ & 3.61 & 4.00 & 5 & 1.166 & 1.359 \\
\hline 11 & I Challenges the way we do things at work. & 3.62 & 4.00 & 4 & 1.371 & 1.880 \\
\hline 12 & $\begin{array}{l}\text { I clearly communicate a positive and hopeful } \\
\text { outlook for the future of our organization. }\end{array}$ & 4.22 & 4.00 & 5 & .746 & .557 \\
\hline 13 & $\begin{array}{l}\text { I give people a lot of discretion to make their } \\
\text { own decisions. }\end{array}$ & 2.76 & 2.00 & 2 & 1.333 & 1.777 \\
\hline 14 & $\begin{array}{l}\text { I spend time and energy making certain that } \\
\text { people adhere to the values that have been } \\
\text { agreed on. }\end{array}$ & 1.93 & 2.00 & 2 & .884 & .781 \\
\hline 15 & I praises people for a job well done & 4.28 & 4.00 & 5 & .825 & .681 \\
\hline 16 & $\begin{array}{l}\text { I look for innovative ways we can improve what } \\
\text { we do in this organization. }\end{array}$ & 4.28 & 4.00 & 5 & .717 & .515 \\
\hline 17 & $\begin{array}{l}\text { I show others how their long-term future } \\
\text { interests can be realized by enlisting in a } \\
\text { common vision. }\end{array}$ & 3.89 & 4.00 & 5 & 1.165 & 1.358 \\
\hline 18 & $\begin{array}{l}\text { I develop cooperative relationships with the } \\
\text { people he or she works with. }\end{array}$ & 4.34 & 5.00 & 5 & .970 & .942 \\
\hline 19 & $\begin{array}{l}\text { I let others know his or her beliefs on how to } \\
\text { best run the organization he or she leads. }\end{array}$ & 3.44 & 4.00 & 4 & .823 & .677 \\
\hline 20 & $\begin{array}{l}\text { I give the members of the team lots of } \\
\text { appreciation and support for their contributions. }\end{array}$ & 3.67 & 4.00 & 5 & 1.127 & 1.271 \\
\hline 21 & $\begin{array}{l}\text { I ask "What can we learn?" when things do not } \\
\text { go as expected. }\end{array}$ & 3.28 & 3.00 & 2 & 1.151 & 1.324 \\
\hline 22 & $\begin{array}{l}\text { I look ahead and forecasts what he or she } \\
\text { expects the future to be like. }\end{array}$ & 3.89 & 4.00 & 5 & 1.65 & 1.358 \\
\hline 23 & $\begin{array}{l}\text { I create an atmosphere of mutual trust in the } \\
\text { projects he or she leads. }\end{array}$ & 4.56 & 5.00 & 5 & .566 & .320 \\
\hline 24 & $\begin{array}{l}\text { I am consistent in practicing the values he or she } \\
\text { espouses. }\end{array}$ & 3.35 & 4.00 & 4 & 1.395 & 1.945 \\
\hline 25 & I find ways to celebrate accomplishments. & 3.61 & 4.00 & 5 & 1.166 & 1.359 \\
\hline 26 & $\begin{array}{l}\text { I experiments and takes risks with new } \\
\text { approaches to his or her work even when there } \\
\text { is a chance of failure. }\end{array}$ & 3.62 & 4.00 & 4 & 1.3 & 1.880 \\
\hline 27 & $\begin{array}{l}\text { I am contagiously excited and enthusiastic about } \\
\text { future possibilities }\end{array}$ & 3.94 & 4.00 & 4 & 1.051 & 1.104 \\
\hline 28 & $\begin{array}{l}\text { I get others to feel a sense of ownership for the } \\
\text { projects they work on. }\end{array}$ & 4.12 & 4.00 & 5 & .956 & .915 \\
\hline 29 & $\begin{array}{l}\text { I makes sure the work group sets clear goals, } \\
\text { makes plans, and establishes milestones for the } \\
\text { projects he or she leads }\end{array}$ & 3.89 & 4.00 & 5 & 1.165 & 1.358 \\
\hline 30 & $\begin{array}{l}\text { I make it a point to tell the rest of the } \\
\text { organization about the good work done by his or } \\
\text { her group. }\end{array}$ & 4.56 & 5.00 & 5 & .566 & .320 \\
\hline
\end{tabular}

\section{Note: $S T D=$ Standard}

Demographic factors frequencies for leadership practices observer assessment

Table 5 shows that only the female $85(100 \%)$ were participate in this study with age group 23-31 years old were $49(57.6 \%)$ and $32-40$ years old were $35(41.2 \%), 41-49$ years old were $1(1.2 \%)$. however near to $72(84.7 \%)$ participants were general nursing diploma holder, and $5(5.9 \%)$ were hold a degree of bachelor of sciences in nursing post Registered nursing and only 8 (9.4\%) participants with degree of bachelor of sciences in nursing generic. Frequency percentage of experience of participants and the results were 1-9 years $62(72.9 \%)$ in majority, 10 -18 years 23 (27.1\%). 
Table 5

\begin{tabular}{|c|c|c|c|c|}
\hline \multicolumn{3}{|c|}{ Demographic Variable } & Frequency & Valid Percent \\
\hline \multirow[t]{2}{*}{ Gender: } & Female & & 85 & $100 \%$ \\
\hline & 23-31 years & & 49 & $57.6 \%$ \\
\hline \multirow{4}{*}{ Age: } & $32-40$ years & & 35 & $41.2 \%$ \\
\hline & 41-49 years & & 1 & $1.2 \%$ \\
\hline & Total & & 85 & $100 \%$ \\
\hline & 1 & years & 62 & $72.9 \%$ \\
\hline \multirow[t]{3}{*}{ Experience: } & $10-18$ years & & 23 & $27.1 \%$ \\
\hline & Total & & 85 & $100 \%$ \\
\hline & General Nursing (Diploma) & & 72 & $84.7 \%$ \\
\hline \multirow[t]{2}{*}{ Qualifications: } & Bachelor of Science in Nursing (Post RN) & & 5 & $5.9 \%$ \\
\hline & Bachelor of Science in Nursing (Generic) & & 8 & $9.4 \%$ \\
\hline
\end{tabular}

\section{Demographic factors statistics for leadership practices observer assessment}

Table 6 shows that mean, median, mode, standard deviation, variance and the mean value mean $(1.00,1.44,1.27$, $1.54)$, median $(1.00,1.00,1.00,1.00)$, variance $(.000, .273, .200,394)$. And mode is 1 respectively for gender, age, experience, qualification.

\begin{tabular}{lcccc}
\hline Statistics & $\begin{array}{c}\text { Gender of the } \\
\text { participants }\end{array}$ & $\begin{array}{c}\text { Age of the } \\
\text { participants }\end{array}$ & $\begin{array}{c}\text { Experience of the } \\
\text { participants }\end{array}$ & $\begin{array}{c}\text { Qualification of the } \\
\text { participants }\end{array}$ \\
\hline $\mathrm{N}$ & 85 & 85 & 85 & 85 \\
Mean & 1.00 & 1.44 & 1.27 & 1.54 \\
Median & 1.00 & 1.00 & 1.00 & 1.00 \\
Mode & 1 & 1 & 1 & 1 \\
Std. Deviation & .000 & .522 & .447 & .628 \\
Variance & .000 & .273 & .200 & .394 \\
\hline
\end{tabular}

Figure5 shows that only the female $85(100 \%)$ were participate in this study.

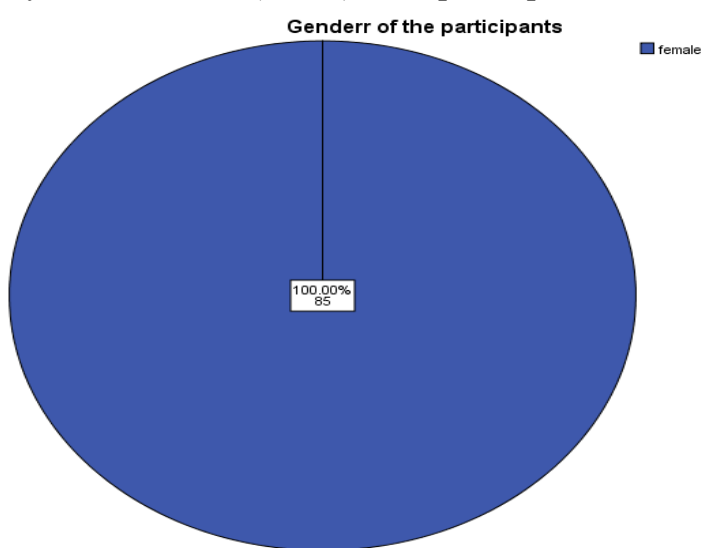

Figure 5

Figure 6 shows that age group 23-31 years old were 49 (57.6\%) and 32-40 years old were 35 (41.2\%), 41-49 years old were $1(1.2 \%)$.

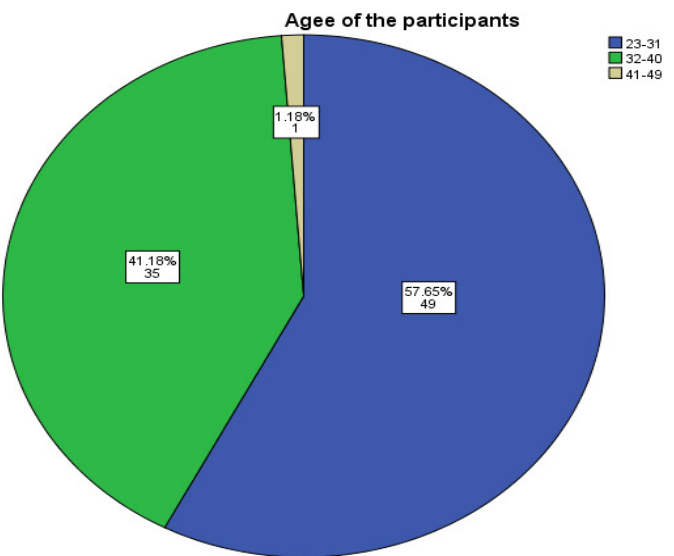

Figure 6 
Figure 7 shows that frequency percentage of experience of participants and the results were 1-9 years 62 $(72.9 \%)$ in majority, $10-18$ years $23(27.1 \%)$.

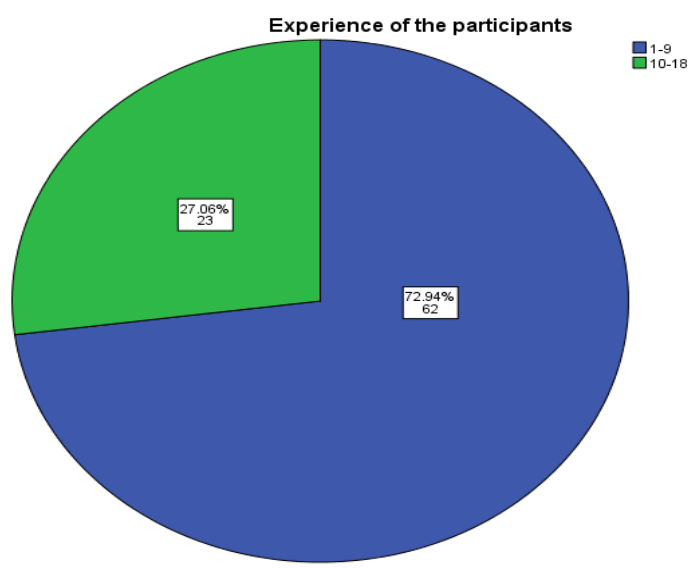

Figure 7

Figure 8 shows that $72(84.7 \%)$ participants were general nursing diploma holder, and $5(5.9 \%)$ were hold a degree of bachelor of sciences in nursing post Registered nursing and only 8 (9.4\%) participants with degree of bachelor of sciences in nursing generic.

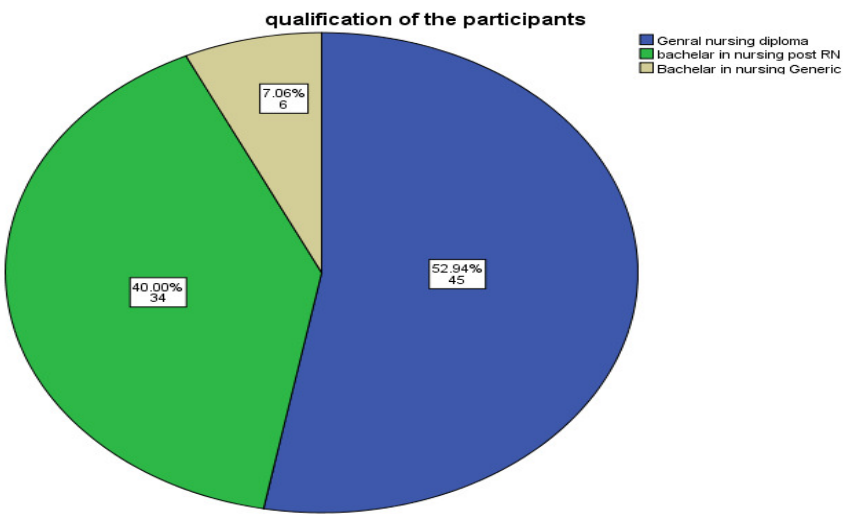

Figure 8

Leadership practices - Observer perception frequency

Table 7 shows the participants response on the items of Leadership practices -observer perception and frequency of participants from rarely or Very Seldom $=1$, Once in a While $=2$ Sometimes $=3$ Fairly Often $=4$ Very frequently or Almost Always $=5$ and the result revealed that $3(3.5 \%)$ participant go with rarely, $16(18.8 \%)$ Once in a While, $10(11.8 \%)$ Sometimes, 25 (29.4\%) Fairly Often, and majority31 (36.5\%) were agree with Almost Always regarding the "seek out challenging opportunities that test his or her skills and abilities". $11(12.9 \%)$ agree with Rarely, 18(21.2\%) agree with Once in a While,19 (22.4\%) participants response as Sometimes and majority 22 $(25.9 \%)$ were response as Fairly Often and 15(17.6\%) in response of item two which was "describe the kind of future he or she would like for us to create together". In the response of item three which was "involve others in planning the actions that will be taking”. 10 (11.8\%) agree with rarely, majority 19 (22.4\%) Once in a While, 10 (11.8\%) select Sometimes 19 (22.4\%) agreed with Fairly Often and 27 (31.8\%) were select Almost Always.

Item four was 'is clear about his or her own philosophy of leadership' and participants respond as 12 (14.1\%) rarely, majority $30(35.3 \%)$ Once ina While, only $16(18.8 \%)$ agree with Sometimes, $16(18.8 \%)$ Fairly Often and $11(12.9 \%)$ agree with Almost Always. In the reaction of question five which was "take the time to celebrate accomplishments when project milestones are reached" $14(16.5 \%)$ rarely, majority 22 (25.9\%) Once in a While, 8 (9.4\%) Sometimes, 26 (30.6\%) agree with Fairly Often, 15 (17.6\%) agreed with Almost Always. In the reaction of item six which was "stay up-to-date on the most recent developments affecting our organization" only $3(3.5 \%)$ rarely, $6(7.1 \%)$ agree with Once in a While, $15(17.6 \%)$ Sometimes and $30(35.3 \%)$ agreed with Fairly Often and majority $31(36.5 \%)$ select Almost Always. Item seven was "appeals to others to share his or her dream of the future as their own" and the participant respond as $0 \%$ go with rarely, majority $33(38.8 \%)$ agree with Once in a While, 7 (8.2\%) Sometimes, 21 (24.7\%) Fairly Often, 24 (28.2\%) agree with Almost Always. Item eight was "treat others with dignity and respect." and response was only $4(4.7 \%)$ participants respectively agreed with rarely and only2 (2.4\%) agreed with Once in a While, 33 (38.8\%) Sometimes, majority 42 (49.4\%) Fairly Often, 4 (4.7\%) go with almost always. In the reaction of item nine which was "make certain that the projects he or she leads are broken down into manageable step" 7(8.2\%)agree with rarely, 21 (24.7\%) Once in a While, 15 (17.6\%) Sometimes, 
$16(18.8 \%)$ Fairly often, $26(30.6 \%)$ participants were agreed with almost always. In the reaction of item ten which was "make sure that people are recognized for their contributions to the success of our projects" only 3 (3.5\%) agree with rarely, $16(18.8 \%)$ Once in a While, 10 (11.8\%) Sometimes, 25 (29.4\%) Fairly often, 31 (36.5\%) participants were agreed with almost always.

$11(12.9 \%)$ participants were agreed with rarely, 18 (21.2\%) Once in a While, 19 (22.4\%) Sometimes, 22 (25.9\%) Fairly Often, and majority15 (17.6\%) were agree with Almost Always regarding the "Challenges the way we do things at work".0 \%agree with Rarely, 21(24.7\%) agree with Once in a While, $8(9.4 \%)$ participants response as Sometimes and majority 29(34.1\%) were response as Fairly Often and 27(31.8\%) in response of item twelve which was "clearly communicate a positive and hopeful outlook for the future of our organization". In the response of item thirteen which was "give people a lot of discretion to make their own decisions". 12(14.1\%) agree with rarely, majority $30(35.3 \%)$ Once in a While, 15(17.6\%) select Sometimes 17 (20\%) agreed with Fairly Often and $11(12.9 \%)$ were select Almost Always. Item fourteen was "spend time and energy making certain that people adhere to the values that have been agreed on and participants respond as $14(16.5 \%)$ rarely, majority $22(25.9 \%)$ Once ina While, only 7 (8.2\%) agree with Sometimes, $26(30.6 \%)$ Fairly Often and $16(18.8 \%)$ agree with Almost Always. In the reaction of question fifteen which was "praises people for a job well done" $0 \%$ rarely, $10(11.8 \%)$ Once in a While, 9 (10.6\%) Sometimes, 25 (29.4\%) agree with Fairly Often, majority 41 (48.2\%) agreed with Almost Always. In the reaction of item sixteen which was "look for innovative ways we can improve what we do in this organization" $0 \%$ rarely, only $4(4.7 \%)$ agree with Once ina While, $3(3.5 \%)$ Sometimes and $32(37.6 \%)$ agreed with Fairly Often and majority 46 (54.8\%) select Almost Always. Item seventeen was "show others how their long-term future interests can be realized by enlisting in a common vision" and the participant respond as only $12(14.1 \%)$ go with rarely, majority $18(21.2 \%)$ agree with Once in a While, $19(22.4 \%)$ Sometimes, 21 (24.7\%) Fairly Often, 15 (17.6\%) agree with Almost Always. Item eighteen was "develop cooperative relationships with the people he or she works with." and response was $0 \%$ participants respectively agreed with rarely, majority 33 (38.8\%) agree with Once ina While, 7 (8.2\%) Sometimes, 21 (24.7\%) Fairly Often, 24 (28.2\%) agree with Almost Always.

In the reaction of item nineteen which was "let others know his or her beliefs on how to best run the organization he or she leads" only 4 (4.7\%) agree with rarely, 2 (2.4\%) Once in a While, 33 (38.8\%) Sometimes, 41 (49.4\%) Fairly often, 4 (4.7\%) participants were agreed with almost always. In the reaction of item twenty which was "give the members of the team lots of appreciation and support for their contributions" 0 agree with rarely, 15 (17.6\%) Once in a While, 15 (17.6\%) Sometimes, 19 (22.4\%) Fairly often, 36 (42.4\%) participants were agreed with almost always. 3(3.5\%) participants were agreed with rarely, 18 (21.2\%) Once in a While, $14(16.5 \%)$ Sometimes, 19 (22.4\%) Fairly Often, and majority31(36.5\%) were agree with Almost Always regarding the "ask "What can we learn?" when things do not go as expected". 12 (14.1\%) agree with Rarely, 18(21.2\%) agree with Once ina While, 19 (22.4\%) participants response as Sometimes and majority $21(24.7 \%)$ were response as Fairly Often and $15(17.6 \%)$ in response of item twenty two which was "look ahead and forecasts what he or she expects the future to be like.". In the response of item twenty three which was "create an atmosphere of mutual trust in the projects he or she leads". 0\%agreed with rarely, 10 (11.8\%) Once ina While, 9 (10.6\%) select Sometimes25 (29.4\%) agreed with Fairly Often and $41(48.2 \%)$ were select Almost Always. Item twenty four was "consistent in practicing the values he or she espouses" and participants respond as $5(5.9 \%)$ rarely, majority $17(20 \%)$ Once in a While, only $16(18.8 \%)$ agree with Sometimes, $26(30.6 \%)$ Fairly Often and 21 (24.7\%) agree with Almost Always. In the reaction of question twenty five which was "find ways to celebrate accomplishments." $3(3.5 \%)$ rarely, 16 (18.8\%) Once in a While, 10 (11.8\%) Sometimes, 25 (29.4\%) agree with Fairly Often, majority 31 (36.5\%) agreed with Almost Always.

In the reaction of item twenty six which was "experiments and takes risks with new approaches to his or her work even when there is a chance of failure." $11(12.9 \%)$ rarely, $18(21.2 \%)$ agree with Once in a While, $19(22.4 \%)$ Sometimes and 22 (25.9\%) agreed with Fairly Often and majority 15 (17.6\%) select Almost Always. Item twenty seven was "contagiously excited and enthusiastic about future possibilities" and the participant respond as only 0\%go with rarely, 20 (23.5\%) agree with Once ina While, 12 (14.1\%) Sometimes, 39 (34.1\%) Fairly Often, 24 (28.2\%) agree with Almost Always. Item twenty eight was "get others to feel a sense of ownership for the projects they work on" and response was only 7 (8.2\%) participants respectively agreed with rarely, majority $26(30.6 \%)$ agree with Once in a While, 4 (4.7\%) Sometimes, 28 (32.9\%) Fairly Often, 20 (23.5\%) agree with Almost Always.

In the reaction of item twenty nine which was "makes sure the work group sets clear goals, makes plans, and establishes milestones for the projects he or she leads" only $12(14.1 \%)$ agree with rarely, $18(21.2 \%)$ Once ina While, 19 (22.4\%) Sometimes, 21 (24.7\%) Fairly often, 15 (17.6\%) participants were agreed with almost always. In the reaction of item thirty which was "make it a point to tell the rest of the organization about the good work done by his or her group" 0\% agree with rarely, 10 (11.8\%) Once in a While, 9 (10.6\%) Sometimes, 25 (29.4\%) Fairly often, 41 (48.2\%) participants were agreed with almost always. 
Table 7

\begin{tabular}{|c|c|c|c|c|c|c|}
\hline $\mathbf{S N}$ & Observer questions & $\begin{array}{c}1 \\
\text { f } \%\end{array}$ & $\begin{array}{c}2 \\
\text { f \% }\end{array}$ & $\begin{array}{c}3 \\
\text { f \% }\end{array}$ & $\begin{array}{c}4 \\
\text { f \% }\end{array}$ & $\begin{array}{c}5 \\
\text { f \% }\end{array}$ \\
\hline \multirow[t]{2}{*}{1} & Seeks out challenging opportunities that test his or her & 3 & 16 & 10 & 25 & 31 \\
\hline & skills and abilities. & $3.5 \%$ & $18.8 \%$ & $11.8 \%$ & $29.4 \%$ & $36.5 \%$ \\
\hline \multirow[t]{2}{*}{2} & Describes the kind of future he or she would like for & 11 & 18 & 19 & 22 & 15 \\
\hline & us to create together. & $12.9 \%$ & $21.2 \%$ & $22 . .4 \%$ & $25.9 \%$ & $17.6 \%$ \\
\hline \multirow[t]{2}{*}{3} & Involves others in planning the actions that will be & 10 & 19 & 10 & 19 & 27 \\
\hline & taking. & $11.8 \%$ & $22.4 \%$ & $11.8 \%$ & $22.4 \%$ & $31.8 \%$ \\
\hline \multirow[t]{2}{*}{4} & Is clear about his or her own philosophy of & 12 & 30 & 16 & 16 & 11 \\
\hline & leadership? & $14.1 \%$ & $35.3 \%$ & $18.8 \%$ & $18.8 \%$ & $12.9 \%$ \\
\hline \multirow[t]{2}{*}{5} & Takes the time to celebrate accomplishments when & 14 & 22 & 8 & 26 & 15 \\
\hline & project milestones are reached. & $16.5 \%$ & $25.9 \%$ & $9.4 \%$ & $30.6 \%$ & $17.6 \%$ \\
\hline \multirow[t]{2}{*}{6} & Stays up-to-date on the most recent developments & 3 & 6 & 15 & 30 & 31 \\
\hline & affecting our organization. & $3.5 \%$ & $7.1 \%$ & $17.6 \%$ & $35.3 \%$ & $36.5 \%$ \\
\hline \multirow[t]{2}{*}{7} & Appeals to others to share his or her dream of the & 0 & 33 & 7 & 21 & 24 \\
\hline & future as their own. & & $38.8 \%$ & $8.2 \%$ & $24.7 \%$ & $28.2 \%$ \\
\hline \multirow[t]{2}{*}{8} & Treats others with dignity and respect. & 4 & 2 & 33 & 42 & 4 \\
\hline & & $4.7 \%$ & $2.4 \%$ & $38.8 \%$ & $49.4 \%$ & $4.7 \%$ \\
\hline \multirow[t]{2}{*}{9} & Makes certain that the projects he or she leads are & 7 & 21 & 15 & 16 & 26 \\
\hline & broken down into manageable step. & $8.2 \%$ & $24.7 \%$ & $17.6 \%$ & $18.8 \%$ & $30.6 \%$ \\
\hline \multirow[t]{2}{*}{10} & Makes sure that people are recognized for their & 3 & 16 & 10 & 25 & 31 \\
\hline & contributions to the success of our projects. & $3.5 \%$ & $18.8 \%$ & $11.8 \%$ & $29.4 \%$ & $36.5 \%$ \\
\hline \multirow[t]{2}{*}{11} & Challenges the way we do things at work. & 11 & 18 & 19 & 22 & 15 \\
\hline & & $12.9 \%$ & $21.2 \%$ & $22.4 \%$ & $25.9 \%$ & $17.6 \%$ \\
\hline \multirow[t]{2}{*}{12} & Clearly communicates a positive and hopeful outlook & 0 & 21 & 8 & 29 & 27 \\
\hline & for the future of our organization. & & $24.7 \%$ & $9.4 \%$ & $34.1 \%$ & $31.8 \%$ \\
\hline \multirow[t]{2}{*}{13} & Gives people a lot of discretion to make their own & 12 & 30 & 15 & 17 & 11 \\
\hline & decisions. & $14.1 \%$ & $35.3 \%$ & $17.6 \%$ & $20.0 \%$ & $12.9 \%$ \\
\hline \multirow[t]{2}{*}{14} & Spends time and energy making certain that people & 14 & 22 & 7 & 26 & 16 \\
\hline & adhere to the values that have been agreed on. & $16.5 \%$ & $25.9 \%$ & $8.2 \%$ & $30.6 \%$ & $18.8 \%$ \\
\hline \multirow[t]{2}{*}{15} & praises people for a job well done & 0 & 10 & 9 & 25 & 41 \\
\hline & & & $11.8 \%$ & $10.6 \%$ & $29.4 \%$ & $48.2 \%$ \\
\hline \multirow[t]{2}{*}{16} & Looks for innovative ways we can improve what we & 0 & 4 & 3 & 32 & 46 \\
\hline & do in this & & $4.7 \%$ & $3.5 \%$ & $37.6 \%$ & $54.8 \%$ \\
\hline \multirow[t]{2}{*}{17} & Shows others how their long-term future interests can & 12 & 18 & 19 & 21 & 15 \\
\hline & be realized by enlisting in a common vision. & $14.1 \%$ & $21.2 \%$ & $22.4 \%$ & $24.7 \%$ & $17.6 \%$ \\
\hline 18 & Develops cooperative relationships with the people he & 0 & 33 & 7 & 21 & 24 \\
\hline & or she w & & $38.8 \%$ & $8.2 \%$ & $24.7 \%$ & $28.2 \%$ \\
\hline 19 & Let's others know his or her beliefs on how to best run & 4 & 2 & 33 & 41 & 4 \\
\hline & the organization he or she leads. & $4.7 \%$ & $2.4 \%$ & $38.8 \%$ & $49.4 \%$ & $4.7 \%$ \\
\hline 20 & Gives the members of the team lots of appreciation & 0 & 15 & 15 & 19 & 36 \\
\hline & and support for their contributions. & & $17.6 \%$ & $17.6 \%$ & $22.4 \%$ & $42.4 \%$ \\
\hline 21 & Asks "What can we learn?" when things do not go as & 3 & 18 & 14 & 19 & 31 \\
\hline & expected. & 3.5 & $21.2 \%$ & $16.5 \%$ & $22.4 \%$ & $36.5 \%$ \\
\hline 22 & Looks ahead and forecasts what he or she expects the & 12 & 18 & 19 & 21 & 15 \\
\hline & future to be like. & $14.1 \%$ & $21.2 \%$ & $22.4 \%$ & $24.7 \%$ & $17.6 \%$ \\
\hline 23 & Creates an atmosphere of mutual trust in the projects & 0 & 10 & 9 & 25 & 41 \\
\hline & he or she leads. & & $11.8 \%$ & $10.6 \%$ & $29.4 \%$ & $48.2 \%$ \\
\hline 24 & Is consistent in practicing the values he or she & 5 & 17 & 16 & 26 & 21 \\
\hline & espouses. & $5.9 \%$ & $20.0 \%$ & $18.8 \%$ & $30.6 \%$ & $24.7 \%$ \\
\hline 25 & Finds ways to celebrate accomplishments. & 3 & 16 & 10 & 25 & 31 \\
\hline & & $3.5 \%$ & $18.8 \%$ & $11.8 \%$ & $29.4 \%$ & $36.5 \%$ \\
\hline 26 & Experiments and takes risks with new approaches to & 11 & 18 & 19 & 22 & 15 \\
\hline & his or her work even when there is a chance of failure. & $12.9 \%$ & $21.2 \%$ & $22.4 \%$ & $25.9 \%$ & $17.6 \%$ \\
\hline 27 & Is contagiously excited and enthusiastic about future & 0 & 20 & 12 & 29 & 24 \\
\hline & possibilities & & $23.5 \%$ & $14.1 \%$ & $34.1 \%$ & $28.2 \%$ \\
\hline 28 & Gets others to feel a sense of ownership for the & 7 & 26 & 4 & 28 & 20 \\
\hline & projects they work on. & $8.2 \%$ & $30.6 \%$ & $4.7 \%$ & $32.9 \%$ & $23.5 \%$ \\
\hline
\end{tabular}




\begin{tabular}{|c|c|c|c|c|c|c|}
\hline SN & Observer questions & $\begin{array}{c}1 \\
\mathbf{f} \%\end{array}$ & $\begin{array}{c}2 \\
\mathbf{f} \%\end{array}$ & $\begin{array}{c}3 \\
\mathbf{f} \%\end{array}$ & $\begin{array}{c}4 \\
\mathrm{f} \%\end{array}$ & $\begin{array}{c}5 \\
\mathbf{f} \%\end{array}$ \\
\hline 29 & $\begin{array}{l}\text { Makes sure the work group sets clear goals, makes } \\
\text { plans, and establishes milestones for the } \\
\text { projects he or she leads }\end{array}$ & $\begin{array}{l}12 \\
14.1 \%\end{array}$ & $\begin{array}{l}18 \\
21.2 \%\end{array}$ & $\begin{array}{l}19 \\
22.4 \%\end{array}$ & $\begin{array}{l}21 \\
24.7 \%\end{array}$ & $\begin{array}{l}15 \\
17.6 \%\end{array}$ \\
\hline 30 & $\begin{array}{l}\text { Makes it a point to tell the rest of the organization } \\
\text { about the good work done by his or her group. }\end{array}$ & 0 & $\begin{array}{l}10 \\
11.8 \%\end{array}$ & $\begin{array}{l}9 \\
10.6 \%\end{array}$ & $\begin{array}{l}25 \\
29.4 \%\end{array}$ & $\begin{array}{l}41 \\
48.2 \%\end{array}$ \\
\hline
\end{tabular}

Note: Rarely or Very Seldom $=1$, Once ina While $=2$ Sometimes $=3$ Fairly Often $=4$ Very Frequentlyor Almost Always $=5$

Leadership practices-Observer perception statics

Table 8 shows the mean, median, mode, standard deviation, and variance of leadership practices- self assessment. High value of mean is 4.41 for item sixteen that was "Looks for innovative ways we can improve what we do in this organization." and lowest value of mean 2.81 for item four that was "Is clear about his or her own philosophy of leadership?.

Table 8

\begin{tabular}{|c|c|c|c|c|c|c|}
\hline \multirow[t]{2}{*}{ SN } & \multirow[t]{2}{*}{ observer questions } & \multirow[b]{2}{*}{ Mean } & \multirow[b]{2}{*}{ Median } & \multicolumn{3}{|c|}{ Std. } \\
\hline & & & & Mode & Deviation & Variance \\
\hline 1 & $\begin{array}{l}\text { Seeks out challenging opportunities that test his } \\
\text { or her skills and abilities. }\end{array}$ & 3.76 & 4.00 & 5 & 1.291 & 1.515 \\
\hline 2 & $\begin{array}{l}\text { Describes the kind of future he or she would like } \\
\text { for us to create together. }\end{array}$ & 3.14 & 3.00 & 4 & 1.302 & 1.694 \\
\hline 3 & $\begin{array}{l}\text { Involves others in planning the actions that will } \\
\text { be taking. }\end{array}$ & 3.40 & 4.00 & 5 & 1.433 & 2.052 \\
\hline 4 & $\begin{array}{l}\text { Is clear about his or her own philosophy of } \\
\text { leadership? }\end{array}$ & 2.81 & 3.00 & 2 & 1.368 & 1.607 \\
\hline 5 & $\begin{array}{l}\text { Takes the time to celebrate accomplishments } \\
\text { when project milestones are reached. }\end{array}$ & 3.07 & 3.00 & 4 & 1.395 & 1.947 \\
\hline 6 & $\begin{array}{l}\text { Stays up-to-date on the most recent } \\
\text { developments affecting our organization. }\end{array}$ & 3.94 & 4.00 & 5 & 1.073 & 1.515 \\
\hline 7 & $\begin{array}{l}\text { Appeals to others to share his or her dream of } \\
\text { the future as their own. }\end{array}$ & 3.42 & 4.00 & 2 & 1.267 & 1.604 \\
\hline 8 & Treats others with dignity and respect. & 3.47 & 4.00 & 4 & .825 & .681 \\
\hline 9 & $\begin{array}{l}\text { Makes certain that the projects he or she leads } \\
\text { are broken down into manageable step. }\end{array}$ & 3.39 & 3.00 & 5 & 1.364 & 1.859 \\
\hline 10 & $\begin{array}{l}\text { Makes sure that people are recognized for their } \\
\text { contributions to the success of our projects. }\end{array}$ & 3.76 & 4.00 & 5 & 1.231 & 1.515 \\
\hline 11 & Challenges the way we do things at work. & 3.14 & 3.00 & 4 & 1.302 & 1.694 \\
\hline 12 & $\begin{array}{l}\text { Clearly communicates a positive and hopeful } \\
\text { outlook for the future of our organization. }\end{array}$ & 3.73 & 4.00 & 4 & 1.159 & 1.343 \\
\hline 13 & $\begin{array}{l}\text { Gives people a lot of discretion to make their } \\
\text { own decisions. }\end{array}$ & 2.82 & 3.00 & 2 & 1.274 & 1.623 \\
\hline 14 & $\begin{array}{l}\text { Spends time and energy making certain that } \\
\text { people adhere to the values that have been } \\
\text { agreed on. }\end{array}$ & 3.09 & 3.00 & 4 & 1.411 & 1.991 \\
\hline 15 & praises people for a job well done & 4.14 & 4.00 & 5 & 1.025 & 1.051 \\
\hline 16 & $\begin{array}{l}\text { Looks for innovative ways we can improve what } \\
\text { we do in this organization. }\end{array}$ & 4.41 & 5.00 & 5 & 0.776 & .602 \\
\hline 17 & $\begin{array}{l}\text { Shows others how their long-term future } \\
\text { interests can be realized by enlisting in a } \\
\text { common vision. }\end{array}$ & 3.11 & 3.00 & 4 & 1.319 & 1.739 \\
\hline 18 & $\begin{array}{l}\text { Develops cooperative relationships with the } \\
\text { people he or she works with. }\end{array}$ & 3.42 & 4.00 & 2 & 1.267 & 1.6 .4 \\
\hline 19 & $\begin{array}{l}\text { Let's others know his or her beliefs on how to } \\
\text { best run the organization he or she leads. }\end{array}$ & 3.47 & 4.00 & 4 & .825 & .681 \\
\hline 20 & $\begin{array}{l}\text { Gives the members of the team lots of } \\
\text { appreciation and support for their contributions. }\end{array}$ & 3.89 & 4.00 & 5 & 1.145 & 1.310 \\
\hline 21 & $\begin{array}{l}\text { Asks "What can we learn?" when things do not } \\
\text { go as expected. }\end{array}$ & 3.67 & 4.00 & 5 & 1.267 & 1.604 \\
\hline 22 & Looks ahead and forecasts what he or she & 3.11 & 3.00 & 4 & 1.319 & 1.739 \\
\hline
\end{tabular}




\begin{tabular}{|c|c|c|c|c|c|c|}
\hline $\mathbf{S N}$ & observer questions & Mean & Median & Mode & Std. & Variance \\
\hline & expects the future to be like. & & & & & \\
\hline 23 & $\begin{array}{l}\text { Creates an atmosphere of mutual trust in the } \\
\text { projects he or she leads. }\end{array}$ & 4.14 & 4.00 & 5 & 1.025 & 1.051 \\
\hline 24 & $\begin{array}{l}\text { Is consistent in practicing the values he or she } \\
\text { espouses. }\end{array}$ & 3.48 & 4.00 & 4 & 1.231 & 1.515 \\
\hline 25 & Finds ways to celebrate accomplishments. & 3.76 & 4.00 & 5 & 1.231 & 1.515 \\
\hline 26 & $\begin{array}{l}\text { Experiments and takes risks with new } \\
\text { approaches to his or her work even when there } \\
\text { is a chance of failure. }\end{array}$ & 3.14 & 3.00 & 4 & 1.302 & 1.694 \\
\hline 27 & $\begin{array}{l}\text { Is contagiously excited and enthusiastic about } \\
\text { future possibilities }\end{array}$ & 3.67 & 4.00 & 4 & 1.127 & 1.271 \\
\hline 28 & $\begin{array}{l}\text { Gets others to feel a sense of ownership for the } \\
\text { projects they work on. }\end{array}$ & 3.33 & 4.00 & 4 & 1.349 & 1.819 \\
\hline 29 & $\begin{array}{l}\text { Makes sure the work group sets clear goals, } \\
\text { makes plans, and establishes milestones for the } \\
\text { projects he or she leads }\end{array}$ & 3.11 & 3.00 & 4 & 1.319 & 1.739 \\
\hline 30 & $\begin{array}{l}\text { Makes it a point to tell the rest of the } \\
\text { organization about the good work done by his or } \\
\text { her group. }\end{array}$ & 4.14 & 4.00 & 5 & 1.025 & 1.051 \\
\hline
\end{tabular}

\section{Note: STD $=$ Standard}

Normality of data for leadership practices self-assessment

Table 9 shows the significance of data normality and $\mathrm{p} \leq .200$ for Kolmogorov-Smirnov and $\mathrm{p} \leq .444$ for Shapiro-Wilk.

Table 9

\begin{tabular}{ccccccc}
\hline & \multicolumn{3}{c}{ Kolmogorov-Smirnov $^{\mathrm{a}}$} & \multicolumn{3}{c}{ Shapiro-Wilk } \\
\cline { 2 - 7 } Leadership Practices - Self & Statistic & $\mathrm{df}$ & Sig. & Statistic & df & Sig. \\
Assessment & .069 & 87 & $.200^{*}$ & .987 & 87 & .560 \\
\hline
\end{tabular}

\section{Note:*. This is a lower bound of the true significance.}

Figure 9 and 10 shows that the normal distribution of data.

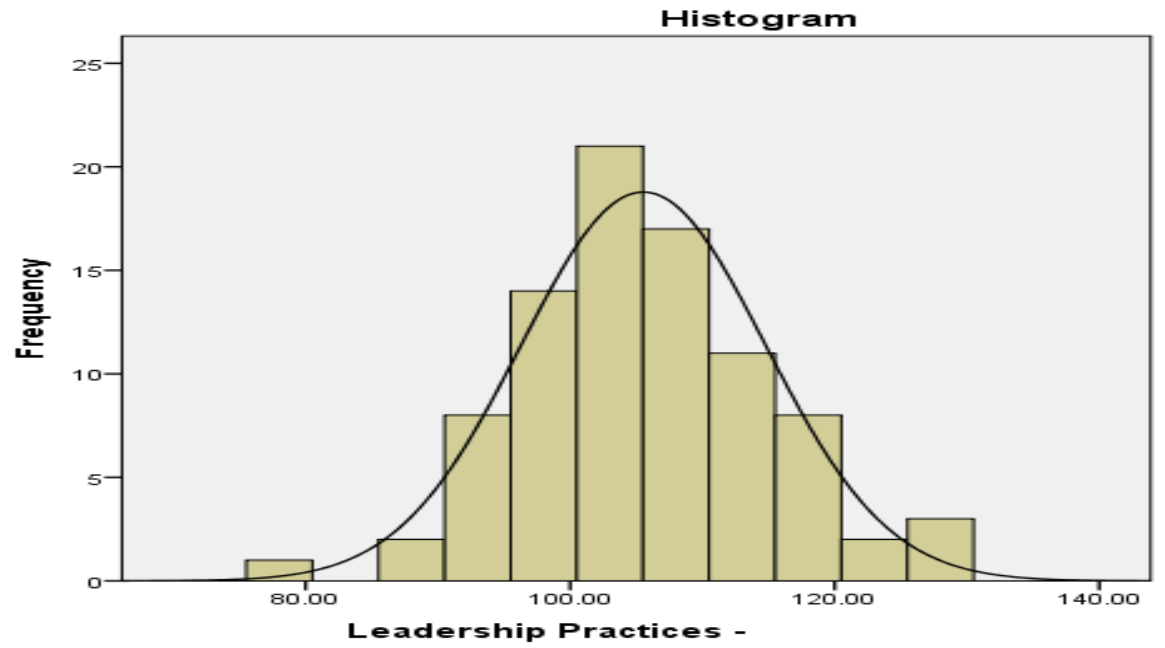

Figure 9 


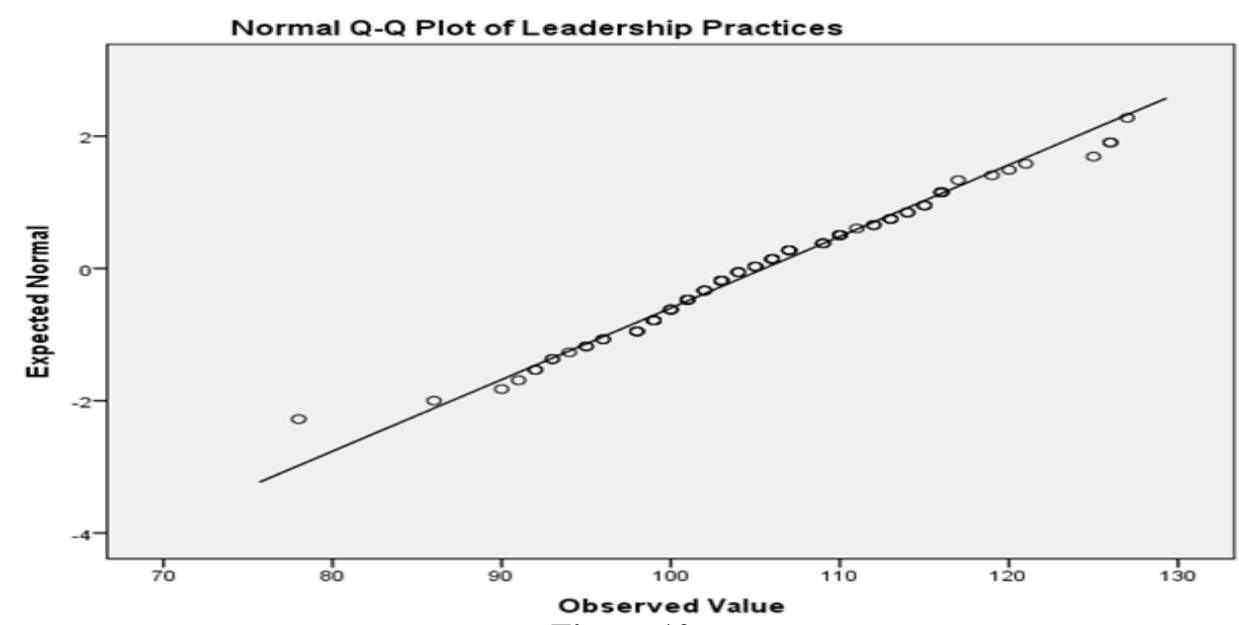

Figure 10

Normality of data for leadership practices observer assessment

Table 10 shows the significance of data normality and $\mathrm{p} \leq .200$ for Kolmogorov-Smirnov and $\mathrm{p} \leq .444$ for Shapiro-Wilk.

Table 10

\begin{tabular}{|c|c|c|c|c|c|c|}
\hline & \multicolumn{3}{|c|}{ Kolmogorov-Smirnov ${ }^{\mathrm{a}}$} & \multicolumn{3}{|c|}{ Shapiro-Wilk } \\
\hline & Statistic & Df & Sig. & Statistic & df & Sig. \\
\hline leadership practices perceived by nurses & .059 & 87 & $.200^{*}$ & .987 & 87 & .580 \\
\hline
\end{tabular}

Note: *. This is a lower bound of the true significance.

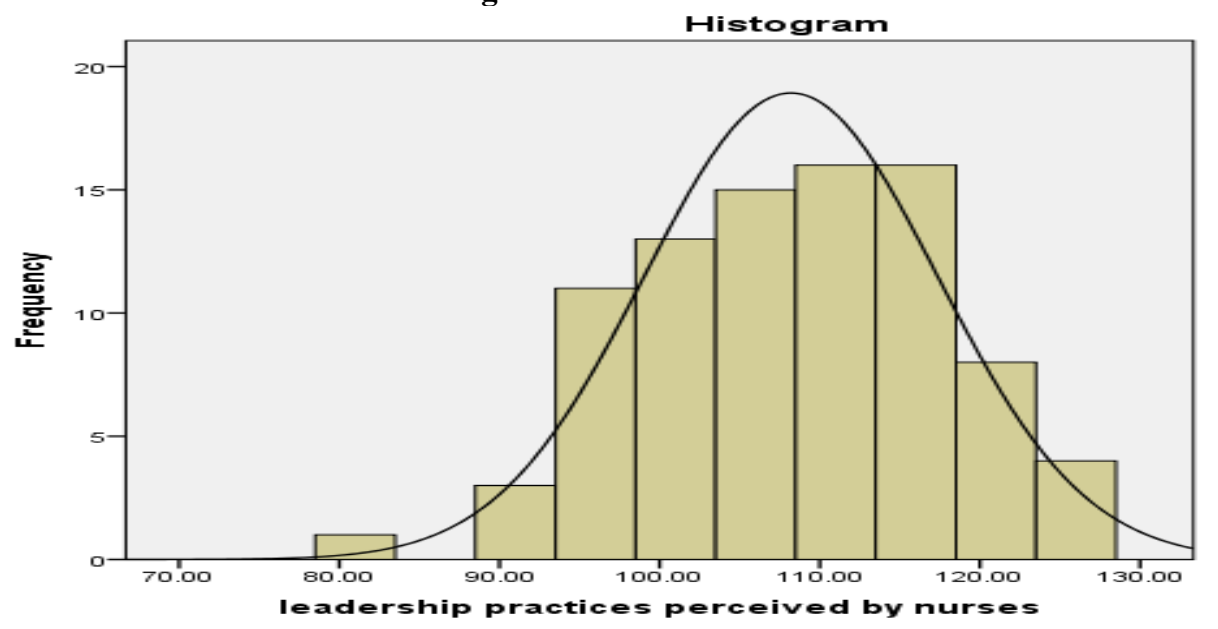

Figure 11

Figure 11 shows that the normal distribution of data.

Correlations between leadership practices self-assessment and perception of subordinates

Descriptive Statistics

Table 11

\begin{tabular}{lcccc}
\hline & & Mean & Std. Deviation & $\mathrm{N}$ \\
\hline Leadership Practices - self assessment & 105.528 & 9.23824 & 86 \\
leadership practices - perception & of & 108.195 & 9.16748 & 86
\end{tabular}
subordinates

Table 12 shows that the positive linear correlation between leadership practices self-assessment and perception of subordinates regarding leadership practices and the $\mathrm{p}=.345$. 
Table 12

Correlations

\begin{tabular}{|c|c|c|c|}
\hline & & $\begin{array}{l}\text { Leadership Practices - } \\
\text { self assessment }\end{array}$ & $\begin{array}{l}\text { leadership practices } \\
\text { perceived by nurses }\end{array}$ \\
\hline \multirow{3}{*}{ Leadership Practices - Observer } & Pearson Correlation & 1 & .103 \\
\hline & Sig. (2-tailed) & & .345 \\
\hline & $\mathrm{N}$ & 87 & 87 \\
\hline \multirow{3}{*}{$\begin{array}{l}\text { leadership practices perceived by } \\
\text { nurses }\end{array}$} & Pearson Correlation & .103 & 1 \\
\hline & Sig. (2-tailed) & .345 & \\
\hline & $\mathrm{N}$ & 87 & 87 \\
\hline
\end{tabular}

\section{DISCUSSION}

The focus of this study was to identify the self-assessment and the subordinate's assessment of leadership practices of the first line nurse manager and determine the relationship between them. The study findings show a significant positive relationship between the manager's self-assessment and the subordinate's assessment of leadership practices.

Kouzes and Posner's (1987) model of leadership provided die conceptual framework for this study. They describe the five leadership practices and ten behavioral commitments that are linked to extraordinary leaders. The leadership practices are: challenging the process, inspiring a shared vision, enabling others to act, modeling the way, and encouraging the heart. The ten behavioral commitments directly relate to the leadership practices. The concept of Kouzes and Posner's leadership model emphasizes that it is the star manager who consistently uses all five leadership practices and ten behavioral commitments and becomes an extraordinary leader(J. M. Kouzes \& Posner, 1987).

A study conducted in 2012 regarding leadership practices perceived by nurses and result revealed that the seven out of 10 nursing staff held positive perceptions about leadership ethics and their professional development. Over one-third of nursing staff were dissatisfied with the nursing process and with their feedback and rewards, while only four out of 10 evaluated their nursing director either in a positive or negative way. There were no significant differences regarding their perceptions when different background variables were taken into account(Eneh et al., 2012).

In related studies it was discovered that it was easy to talk about leadership, but difficult to practice (Lee, Smith, \& Cioci, 1993). The authors contended that becoming an outstanding leader was difficult, but within each manager is the capacity to do so. Author identified that inadequate educational preparation of nurse managers has limited their ability to become excellent leaders(Cress, 1996). Meighan (1990) also notes that nurse managers are often unprepared to meet the challenge of outstanding leadership. The findings in this study support these notions(Meighan, 1990).

The demographic data in this study also revealed a variety in experience, and educational profile for the leadership. Years of experience ranged from 1-27 years and the gender was deferent from others studies because only female participate in this study, and the highest educational level obtained varied, BSN, no any manager holding an MSN in nursing.

\section{LIMITATIONS OF THE STUDY}

This study found many limitations;

$>$ Time duration was too short.

$>$ The study design is convient sample technique.

$>$ Likert scale questionnaire has been used in this study.

$>$ Data collection was faced lot of issues.

The respondents of the study have very careless attitude regarding filling questionnaire.

Participants of study have no idea about the importance of the filling questionnaire sincerely.

\section{CONCLUSION AND RECOMMENDATION}

In summary, the results of this study support the existence of a relationship between the self-assessment and the subordinate's assessment. This study also indicates that the managers in this study moderately exhibited the leadership practices as identified in Kouzes and Posner's (1987) research.

Implications for Nursing Administration As this study suggests, the managers, as perceived by themselves and their subordinates, moderately exhibit extraordinary leadership practices. There is a need for nurse administrators to be cognizant of these practices and recognize that for extraordinary things to be accomplished in an organization the five leadership practices must be exhibited consistently. Attention must be given to the current nurse manager's growth as leaders.

Current educational preparation is varied amongst the nurse managers. Decisions about the future educational 
level and preparation expected of a first line nurse manager are crucial for nurse administrators to determine.

The implications for future research as a result of these study findings are great. First, replication studies are needed to further validate and examine study findings. Ongoing measurement of the leadership practices for the first line nurse managers through self and subordinate assessment would provide valuable insight into the practices of the first line nurse manger and allow for ongoing opportunities of growth and strengthening of the leadership practices.

Future researchers conducting the leadership practices study should exercise caution in the number of subordinates per manager included in the study. They would do well to determine a number of subordinates that would be a representative percentage of die managers to better facilitate the accuracy of the subordinate's perception of the manager's leadership practices

\section{References}

Al-Baradie, R. S. (2014). Encouraging the heart. International Journal of Pediatrics and Adolescent Medicine, 1(1), 11-16.

Clinton, J. R. (2017). The making of a leader: Recognizing the lessons and stages of leadership development: Two Words Publishing, LLC.

Cress, D. L. (1996). A Study of the Leadership Practices of the First Line Nurse Manager.

Gayathiri, R., Ramakrishnan, L., Babatunde, S., Banerjee, A., \& Islam, M. (2013). Quality of work life-Linkage with job satisfaction and performance. International Journal of Business and Management Invention, 2(1), $1-8$.

Heppell, L. (2016). Strategies to Improve Patient Satisfaction and Organizational Performance in Health Care. Walden University.

Keenan, A. M., Mutterback, E. E., Velthuizen, K. M., Pantalone, M. E., \& Gossack-Keenan, K. L. (2018). Perceptions of the effectiveness of Advanced Practice Nurses on a neurosurgery unit in a Canadian Tertiary Care Centre: A pre-and-post implementation design. International Journal of Nursing Sciences.

Khan, R., Bukhari, A., \& Channar, Z. (2016). Effects of Leadership Style on Health Care Organizational Performance: A Survey of Selected Tertiary Care Hospital in Karachi, Pakistan. Int J Econ Manag Sci, 5(333), 2.

Kleefstra, S. M., Zandbelt, L. C., de Haes, H. J., \& Kool, R. B. (2015). Trends in patient satisfaction in Dutch university medical centers: room for improvement for all. BMC health services research, 15(1), 112.

Kouzes, J., \& Posner, B. (2013). The five practices of exemplary leadership model. The Five Practices of Exemplary Leadership Model." John Wiley \& Sons, nd Web, 1.

Kouzes, J. M., \& Posner, B. Z. (1987). The leadership challenge: How to get extraordinary things done in organizations San Francisco. Google Scholar.

Lee, V. E., Smith, J. B., \& Cioci, M. (1993). Teachers and principals: Gender-related perceptions of leadership and power in secondary schools. Educational Evaluation and Policy Analysis, 15(2), 153-180.

Lieber, J. L. (2014). How do your patient satisfaction scores measure up? Nursing management, 45(2), 22-25.

McGrath, S. P., Taenzer, A. H., Karon, N., \& Blike, G. (2016). Surveillance Monitoring Management for General Care Units: Strategy, Design, and Implementation. Joint Commission journal on quality and patient safety, 42(7), 293-302.

Meighan, M. M. (1990). The most important characteristics of nursing leaders. Nursing administration quarterly, 15(1), 63-69.

Posner, B. Z., \& Kouzes, J. M. (1988). Development and validation of the leadership practices inventory. Educational and psychological measurement, 48(2), 483-496.

Rost, J. C. (1993). Leadership for the twenty-first century: Greenwood Publishing Group.

Sfantou, D. F., Laliotis, A., Patelarou, A. E., Sifaki-Pistolla, D., Matalliotakis, M., \& Patelarou, E. (2017). Importance of Leadership Style towards Quality of Care Measures in Healthcare Settings: A Systematic Review. Paper presented at the Healthcare.

Shaw, S. (2007). International council of nurses: Nursing leadership: Wiley-Blackwell.

$\mathrm{Xu}$, J.-H. (2017). Leadership theory in clinical practice. Chinese Nursing Research. 


\section{LAHORE SCHOOL OF NURSING THE UNIVERSITY Of LAHORE}

\section{UHE
UNIVERSITY OF}

Dear participants,

This survey is being done by Firdous Akbar in the supervision of preceptor Sir Muhammad Sabir Department of Lahore School of Nursing at The University of Lahore. The purpose of this survey is to examine the leadership practices of first line nurse manager. This survey is only for the academic purpose and the personal identity will be kept confidential. Thank you for your valuable time and opinion.

Participant Signature

Section A: Demographics

Respond by circling (O) or ticking ( ) the most appropriate responses

\begin{tabular}{|c|c|c|c|}
\hline Gender & $\begin{array}{l}\square \text { Female } \\
\square \text { Male }\end{array}$ & Experience & $\begin{array}{l}\text { ㅁ } 1 \text { - } 9 \text { years } \\
\text { } 10 \text { - } 18 \text { years } \\
\text { } 19-27 \text { years } \\
\square 28-36 \text { years }\end{array}$ \\
\hline Age & $\begin{array}{l}\square 23-31 \text { years } \\
\square 32-40 \text { years } \\
\square \text { 41-49 years } \\
\square \text { 50-58 years }\end{array}$ & Qualifications & $\begin{array}{l}\square \text { General Nursing (Diploma) } \\
\square \text { Bachelor of Science in Nursing (Post RN) } \\
\square \text { Bachelor of Science in Nursing (Generic) } \\
\square \text { Master of Science in Nursing (MSN) }\end{array}$ \\
\hline
\end{tabular}

Section B: Leadership Practices - Self assessment questionnaire

Rarely or Very Seldom $=1$, Once in a While $=2$ Sometimes $=3$ Fairly Often $=4$ Very Frequently or Almost Always $=5$.

\begin{tabular}{|c|c|c|c|c|c|c|}
\hline SN & Self-assessment questions & 1 & 2 & 3 & 4 & 5 \\
\hline 1 & $\begin{array}{l}\text { I seek out challenging opportunities that test his or her skills } \\
\text { and abilities. }\end{array}$ & & & & & \\
\hline 2 & $\begin{array}{l}\text { I describe the kind of future he or she would like for us to } \\
\text { create together. }\end{array}$ & & & & & \\
\hline 3 & I involve others in planning the actions that will be taking. & & & & & \\
\hline 4 & I am clear about his or her own philosophy of leadership? & & & & & \\
\hline 5 & $\begin{array}{l}\text { I take the time to celebrate accomplishments when project } \\
\text { milestones are reached. }\end{array}$ & & & & & \\
\hline 6 & $\begin{array}{l}\text { I stay up-to-date on the most recent developments affecting } \\
\text { our organization. }\end{array}$ & & & & & \\
\hline 7 & $\begin{array}{l}\text { I appeals to others to share his or her dream of the future as } \\
\text { their own. }\end{array}$ & & & & & \\
\hline 8 & I treat others with dignity and respect. & & & & & \\
\hline 9 & $\begin{array}{l}\text { I make certain that the projects he or she leads are broken } \\
\text { down into manageable step. }\end{array}$ & & & & & \\
\hline 10 & $\begin{array}{l}\text { I make sure that people are recognized for their contributions } \\
\text { to the success of our projects. }\end{array}$ & & & & & \\
\hline 11 & I Challenges the way we do things at work. & & & & & \\
\hline 12 & $\begin{array}{l}\text { I clearly communicate a positive and hopeful outlook for the } \\
\text { future of our organization. }\end{array}$ & & & & & \\
\hline 13 & I give people a lot of discretion to make their own decisions. & & & & & \\
\hline 14 & $\begin{array}{l}\text { I spend time and energy making certain that people adhere to } \\
\text { the values that have been agreed on. }\end{array}$ & & & & & \\
\hline 15 & I praises people for a job well done & & & & & \\
\hline
\end{tabular}




\begin{tabular}{|c|c|c|c|c|c|c|}
\hline SN & Self-assessment questions & 1 & 2 & 3 & 4 & 5 \\
\hline 16 & $\begin{array}{l}\text { I look for innovative ways we can improve what we do in } \\
\text { this organization. }\end{array}$ & & & & & \\
\hline 17 & $\begin{array}{l}\text { I show others how their long-term future interests can be } \\
\text { realized by enlisting in a common vision. }\end{array}$ & & & & & \\
\hline 18 & $\begin{array}{l}\text { I develop cooperative relationships with the people he or she } \\
\text { works with. }\end{array}$ & & & & & \\
\hline 19 & $\begin{array}{l}\text { I let others know his or her beliefs on how to best run the } \\
\text { organization he or she leads. }\end{array}$ & & & & & \\
\hline 20 & $\begin{array}{l}\text { I give the members of the team lots of appreciation and } \\
\text { support for their contributions. }\end{array}$ & & & & & \\
\hline 21 & $\begin{array}{l}\text { I ask "What can we learn?" when things do not go as } \\
\text { expected. }\end{array}$ & & & & & \\
\hline 22 & $\begin{array}{l}\text { I look ahead and forecasts what he or she expects the future } \\
\text { to be like. }\end{array}$ & & & & & \\
\hline 23 & $\begin{array}{l}\text { I create an atmosphere of mutual trust in the projects he or } \\
\text { she leads. }\end{array}$ & & & & & \\
\hline 24 & I am consistent in practicing the values he or she espouses. & & & & & \\
\hline 25 & I find ways to celebrate accomplishments. & & & & & \\
\hline 26 & $\begin{array}{l}\text { I experiments and takes risks with new approaches to his or } \\
\text { her work even when there is a chance of failure. }\end{array}$ & & & & & \\
\hline 27 & $\begin{array}{l}\text { I am contagiously excited and enthusiastic about future } \\
\text { possibilities }\end{array}$ & & & & & \\
\hline 28 & $\begin{array}{l}\text { I get others to feel a sense of ownership for the projects they } \\
\text { work on. }\end{array}$ & & & & & \\
\hline 29 & $\begin{array}{l}\text { I makes sure the work group sets clear goals, makes plans, } \\
\begin{array}{l}\text { and establishes milestones for the } \\
\text { projects he or she leads }\end{array}\end{array}$ & & & & & \\
\hline 30 & $\begin{array}{l}\text { I make it a point to tell the rest of the organization about the } \\
\text { good work done by his or her group. }\end{array}$ & & & & & \\
\hline
\end{tabular}

(Posner \& Kouzes, 1988)

\section{Section C: Leadership Practices - Observer}

Rarely or Very Seldom $=1$, Once in a While $=2$ Sometimes $=3$ Fairly Often $=4$ Very Frequently or Almost Always $=5$.

\begin{tabular}{|l|l|l|l|l|l|l|}
\hline $\mathbf{S N}$ & Self-assessment questions & $\mathbf{1}$ & $\mathbf{2}$ & $\mathbf{3}$ & $\mathbf{4}$ & $\mathbf{5}$ \\
\hline $\mathbf{1}$ & $\begin{array}{l}\text { Seeks out challenging opportunities that test his or her skills } \\
\text { and abilities. }\end{array}$ & & & & & \\
\hline $\mathbf{2}$ & $\begin{array}{l}\text { Describes the kind of future he or she would like for us to } \\
\text { create together. }\end{array}$ & & & & & \\
\hline $\mathbf{3}$ & Involves others in planning the actions that will be taking. & & & & & \\
\hline $\mathbf{4}$ & Is clear about his or her own philosophy of leadership? & & & & & \\
\hline $\mathbf{5}$ & $\begin{array}{l}\text { Takes the time to celebrate accomplishments when project } \\
\text { milestones are reached. }\end{array}$ & & & & & \\
\hline $\mathbf{6}$ & $\begin{array}{l}\text { Stays up-to-date on the most recent developments affecting } \\
\text { our organization. }\end{array}$ & & & & & \\
\hline $\mathbf{7}$ & $\begin{array}{l}\text { Appeals to others to share his or her dream of the future as } \\
\text { their own. }\end{array}$ & & & & & \\
\hline $\mathbf{8}$ & Treats others with dignity and respect. & & & & \\
\hline $\mathbf{9}$ & $\begin{array}{l}\text { Makes certain that the projects he or she leads are broken } \\
\text { down into manageable step. }\end{array}$ & & & & \\
\hline $\mathbf{1 0}$ & $\begin{array}{l}\text { Makes sure that people are recognized for their contributions } \\
\text { to the success of our projects. }\end{array}$ & & & & & \\
\hline $\mathbf{1 1}$ & Challenges the way we do things at work. & & \\
\hline $\mathbf{1 2}$ & $\begin{array}{l}\text { Clearly communicates a positive and hopeful outlook for the } \\
\text { future of our organization. }\end{array}$ & & & & & \\
\hline $\mathbf{1 3}$ & Gives people a lot of discretion to make their own decisions. & & & & \\
\hline
\end{tabular}




\begin{tabular}{|c|c|c|c|c|c|c|}
\hline SN & Self-assessment questions & 1 & 2 & 3 & 4 & $\mathbf{5}$ \\
\hline 14 & $\begin{array}{l}\text { Spends time and energy making certain that people adhere to } \\
\text { the values that have been agreed on. }\end{array}$ & & & & & \\
\hline 15 & praises people for a job well done & & & & & \\
\hline 16 & $\begin{array}{l}\text { Looks for innovative ways we can improve what we do in } \\
\text { this organization. }\end{array}$ & & & & & \\
\hline 17 & $\begin{array}{l}\text { Shows others how their long-term future interests can be } \\
\text { realized by enlisting in a common vision. }\end{array}$ & & & & & \\
\hline 18 & $\begin{array}{l}\text { Develops cooperative relationships with the people he or she } \\
\text { works with. }\end{array}$ & & & & & \\
\hline 19 & $\begin{array}{l}\text { Let's others know his or her beliefs on how to best run the } \\
\text { organization he or she leads. }\end{array}$ & & & & & \\
\hline 20 & $\begin{array}{l}\text { Gives the members of the team lots of appreciation and } \\
\text { support for their contributions. }\end{array}$ & & & & & \\
\hline 21 & $\begin{array}{l}\text { Asks "What can we learn?" when things do not go as } \\
\text { expected. }\end{array}$ & & & & & \\
\hline 22 & $\begin{array}{l}\text { Looks ahead and forecasts what he or she expects the future } \\
\text { to be like. }\end{array}$ & & & & & \\
\hline 23 & $\begin{array}{l}\text { Creates an atmosphere of mutual trust in the projects he or } \\
\text { she leads. }\end{array}$ & & & & & \\
\hline 24 & Is consistent in practicing the values he or she espouses. & & & & & \\
\hline 25 & Finds ways to celebrate accomplishments. & & & & & \\
\hline 26 & $\begin{array}{l}\text { Experiments and takes risks with new approaches to his or } \\
\text { her work even when there is a chance of failure. }\end{array}$ & & & & & \\
\hline 27 & $\begin{array}{l}\text { Is contagiously excited and enthusiastic about future } \\
\text { possibilities }\end{array}$ & & & & & \\
\hline 28 & $\begin{array}{l}\text { Gets others to feel a sense of ownership for the projects they } \\
\text { work on. }\end{array}$ & & & & & \\
\hline 29 & $\begin{array}{l}\text { Makes sure the work group sets clear goals, makes plans, and } \\
\text { establishes for milestones the for } \\
\text { projects he or she leads }\end{array}$ & & & & & \\
\hline 30 & $\begin{array}{l}\text { Makes it a point to tell the rest of the organization about the } \\
\text { good work done by his or her group. }\end{array}$ & & & & & \\
\hline
\end{tabular}

(Posner \& Kouzes, 1988) 